\title{
Social-ecological traps hinder rural development in southwestern Madagascar
}

\author{
$\underline{\text { Hendrik Hänke }}^{1}, \underline{\text { Jan Barkmann }}^{2}$, Claudia Coral $^{3}$, Elin Enfors Kaustky $^{4}$ and Rainer Marggraf $^{1}$
}

\begin{abstract}
The semiarid Mahafaly region in southwestern Madagascar is not only a unique biodiversity hotspot, but also one of the poorest regions in the world. Crop failures occur frequently, and despite a great number of rural development programs, no effective progress in terms of improved yields, agricultural income, or well-being among farming households has been observed. In addition to the severe development challenges in the region, environmental degradation and the loss of biodiversity are prevailing issues. This paper takes a social-ecological systems perspective to analyze why the region appears locked in poverty. Specifically, we address the socialecological interaction between environmental factors such as low and variable precipitation, the lack of sustainable intensification in agriculture resulting in recalcitrant hunger, and several environmental degradation trends. The study is based on (i) longitudinal data from 150 farming households interviewed at high temporal resolution during the course of 2014, and (ii) extensive recall surveys from the southwestern Madagascar project region. The analysis reveals a complex interplay of pronounced seasonality in income generation due to recurrent droughts and crop failures making local farmers highly risk averse. This interplay results in a gradual depletion of environmental assets and hinders the accumulation of capital in the hands of smallholder farmers, and improvements in agricultural production even where environmental conditions would allow for it. As a result, households are insufficiently buffered and insured against repetitive income and food security shocks. This can be understood as a set of interacting, partly nested social-ecological traps, which entrench the Mahafalian smallholder population in deep poverty while the productivity of the environment declines. We provide new insights on the interplay between hunger, poverty, and loss of environmental assets in a global biodiversity hotspot. Finally, we propose a set of key issues that need to be considered to unlock this severe lock-in and enable transformation toward a more sustainable development in southwestern Madagascar.
\end{abstract}

Key Words: food security; livelihoods; Madagascar; poverty traps; social-ecological traps

\section{INTRODUCTION}

The semiarid Mahafaly region in southwestern Madagascar (SW Madagascar) is a global biodiversity hotspot (Ganzhorn et al. 2001, Waeber et al. 2015) and one of the poorest regions in subSaharan Africa (WFP 2015a, World Bank 2015a). The region is characterized by a unique spiny forest, and although biodiversity loss is proceeding at an alarming rate, the level of endemic species of plants and animals is still extremely high (Jasper and Gardner 2015). Smallholder agriculture and animal husbandry are the main sources of local livelihoods. As in other semiarid areas, a pronounced seasonality of precipitation poses a constraint to production in addition to the low precipitation itself (Barron et al. 2003, Hanisch 2015). Droughts, as well as extended dry spells during the rainy season, occur frequently and have become increasingly problematic over the past decades (Tadross et al. 2008, Hanisch 2015, WFP 2015a). Regional agricultural yields are low by any standard, averaging 1-5 ton/ha for cassava, and 0.5-2 ton/ha for maize (Bayala et al. 1998, Hanisch 2015).

Two seasonal peaks characterize food availability. The first peak coincides with the harvest of annual crops (mainly maize and legumes) around April/May, the second with the harvest of cassava, the main staple crop, in July/August. Often already beginning in November, and steadily increasing until the harvest of annual crops much later, a large number of households (HHs) suffer from severe food shortages (Wüstefeld 2004). Locally, this recurrent hunger season is called kere, sometimes resulting in premature deaths in susceptible fractions of the population(WFP 2015a).

The development challenges in SW Madagascar have not gone unnoticed. In the absence of effective national government interventions, emergency food distribution was regularly organized in recent years, e.g., by the World Food Programme (WFP 2015b). A number of private charities as well as international development cooperation agencies have attempted to improve existing farming systems, reduce malnutrition, improve education, and initiate livelihood diversification. Informally, however, SW Madagascar is known as a "project cemetery," with very little or no effective progress in terms of improved yields, agricultural income, and/or general livelihood improvements for the local population (UNICEF 2011, Hanisch 2015).

In parallel to the severe development challenges, biodiversity conservation is a major international concern in Madagascar (Kull 2014) but conservation policies have only had limited success so far (Kaufmann 2008, Scales 2014). For example, $45 \%$ of the spiny forest was lost in the past 40 years (Brinkmann et al. 2014), and many endemic species are now at the verge of extinction (Ganzhorn et al. 2001, IUCN 2015).

Why is SW Madagascar apparently locked in such a dismal socioeconomic and ecological state? What would it take to turn current trends around, improving local livelihoods while

\footnotetext{
${ }^{1}$ University of Göttingen, Department of Agricultural Economics and Rural Development, Research Unit Environmental- and Resource Economics, ${ }^{2}$ University of Applied Sciences of Darmstadt, Risk- and Sustainability Sciences, ${ }^{3}$ Humboldt University of Berlin, Department of Agricultural Economics, Albrecht Daniel Thaer-Institute of Agricultural and Horticultural Sciences, ${ }^{4}$ Stockholm Resilience Centre, Stockholm University
} 
maintaining biodiversity? A systematic attempt to answer these questions needs a dynamic and detailed appraisal of the tradeoffs as well as the synergies of protection and utilization of the regional landscapes (cf. Scales 2014). Unfortunately, conservation policies, often financed by international donors, have sometimes had a tendency to downplay the problematic socioeconomic impact on local Malagasy communities of ambitious probiodiversity projects (Ghimire 1994, Ferraro 2002, Kaufmann 2008), and local livelihood strategies, such as livestock rearing, have often been regarded as "irrational" (Wüstefeld 2004, Klein et al. 2008). However, it is becoming increasingly clear that policies guiding development investments in the region too often have relied on oversimplified models of regional social-ecological dynamics (Moreau 2008, Kaufmann 2008, Scales 2014) and unfounded myths about Madagascar's environmental history (Kull 2000, Scales 2014).

To avoid reductionist explanatory models, we take a resilienceinspired social-ecological systems approach (Folke et al. 2010) in our study of the Mahafaly region. Specifically, we focus on describing a set of interacting, and partly nested, social-ecological traps that likely have a strong influence on current development pathways in SW Madagascar. This type of perspective allows for the formulation of hypotheses around how social and ecological factors interact, which in turn opens up for constructive solutions to the parallel development and biodiversity challenges that the region faces.

Our results build on a rich empirical dataset from the Mahafaly region, including (i) harvest data from participating households, (ii) a high frequency longitudinal agro-economic survey on $\mathrm{HH}$ cash income and expenditures, (iii) a recall survey on $\mathrm{HH}$ coping strategies in case of food and cash shortages, and (iv) a market participation survey providing a value chain perspective on smallholder farming. We provide a second analytic layer that incorporates findings from the wider SuLaMa project (Sustainable Land Management in Southern Madagascar, http:// www.sulama.de) conducted in the Mahafaly region. These relate to drivers of environmental change (Brinkmann et al. 2014, Götter et al. 2015, Waeber et al. 2015) and biodiversity decline (Ganzhorn et al. 2001), challenges to improve agricultural systems (Hanisch et al. 2013, Hanisch 2015) and natural resource management in the region (Ratovonamana et al. 2013, Andriamparany et al. 2014, Manon 2014, Andriamparany 2015, Ranaivoson et al. 2015), the role of livestock herding including its economic importance (Feldt 2015, Götter 2016, Hänke and Barkmann 2017), socioeconomic characteristics of local households (Hänke et al. 2014, Neudert et al. 2015; Neudert 2013, unpublished data), local value chains (Coral 2014), and recent institutional changes in the region (Götter and Neudert 2015). The already published findings from the larger project are used as a backdrop, against which our own empirical data is analyzed.

\section{SITE DESCRIPTION}

The Mahafaly Plateau is a semiarid area in southwestern Madagascar. It stretches from the littoral in the west to the higher parts of the plateau in the east. The area belongs to the poorest and most disadvantaged areas in Madagascar (INSTAT 2011), which is itself one of the poorest countries in the world (IMF 2015, World Bank 2015b). The large majority of inhabitants are smallholder farmers $(>97 \%)$ and/or livestock herders $(>60 \%$;
Neudert et al. 2015). Local livelihoods fundamentally depend on local natural resources (SuLaMa Marp 2011). In general, malnutrition and hunger are widespread in the area, and have worsened in recent years (FAO and WFP 2014, WFP 2015a).

Rainfall is low, displaying a gradient from roughly $200 \mathrm{~mm} / \mathrm{yr}$ in the west to $600 \mathrm{~mm} / \mathrm{yr}$ in the east (CNA 2015; see Appendix 1 for rainfall in 2014 when this study was conducted). Agronomic droughts have become a chronic problem in recent years, and the frequency of dry spells during the wet season in southern Madagascar has increased (Tadross et al. 2008, WFP 2015b). The littoral is characterized by sandy soils, and the plateau by calcareous soils (Hanisch 2015). Generally, soil quality is poor constraining agricultural productivity through low water holding capacity, low levels of nutrients, and low organic carbon (Andriamparany 2015, Hanisch 2015). On the plateau, groundwater is hardly accessible with the main groundwater level at $70 \mathrm{~m}$ below surface (de Haut de Sigy 1965). In the littoral, groundwater is easily accessible but its salt content is too high for irrigation (Guyot 2002, Hanisch 2015).

In this paper, we analyze the Mahafalian social-ecological system, consisting of rural farm households and their local natural resource base. The system we describe, however, is not an isolated entity. Regional institutions, markets, social networks, family, and clan lineages interact with other social-ecological systems at other scales, i.e., outside the study region. To the extent necessary, these external systems are briefly addressed but we do not claim to provide original insights here.

\section{Environmental degradation in southwestern Madagascar}

Southwestern Madagascar is one of the "hottest biodiversity hotpots" globally (Myers et al. 2000, Ganzhorn et al. 2001, Waeber et al. 2015). Towards the littoral, the natural vegetation consists of dry spiny forest with plant and animal endemism rates of up to $90 \%$ (Fenn 2003, Jasper and Gardner 2015). However, $45 \%$ of forest has been lost in the past four decades (Brinkmann et al. 2014) mainly due to farmland expansion (Waeber et al. 2015). Farming practices are extremely extensive; virtually no advanced agricultural inputs are used (Coral 2014, Hanisch 2015).

The study area includes the Tsimanampetsotse National Park (TNP; see Fig. 1). The management of the national park, and particularly its extension in 2010 (Kiefer 2011), is controversial among local communities. Conflicts are frequent according to our own observations: livestock is banned from the park but herders partly ignore grazing rules (Ratovonamana et al. 2013, Feldt 2015). The animals graze on agricultural residues, on rangelands at the periphery of the villages, and in the remaining forests pressuring regional biodiversity (Ratovonamana et al. 2013, Feldt 2015). Fire clearing natural vegetation for grazing land is a common strategy as is the regular burning as a mean of grassland management (Feldt 2015) that, however, hinders forest regrowth (Kull 2004).

\section{Agricultural risks in SW Madagascar}

With 30 severe droughts and famines documented for southern Madagascar over the past 200 years (Wüstefeld 2004), poorly distributed precipitation and subsequent crop failures have been the norm within the past five years (WFP and UNICEF 2011, WFP 2013, 2015a, FAO and WFP 2014). The intensity and 
Fig. 1. Map of the study area.

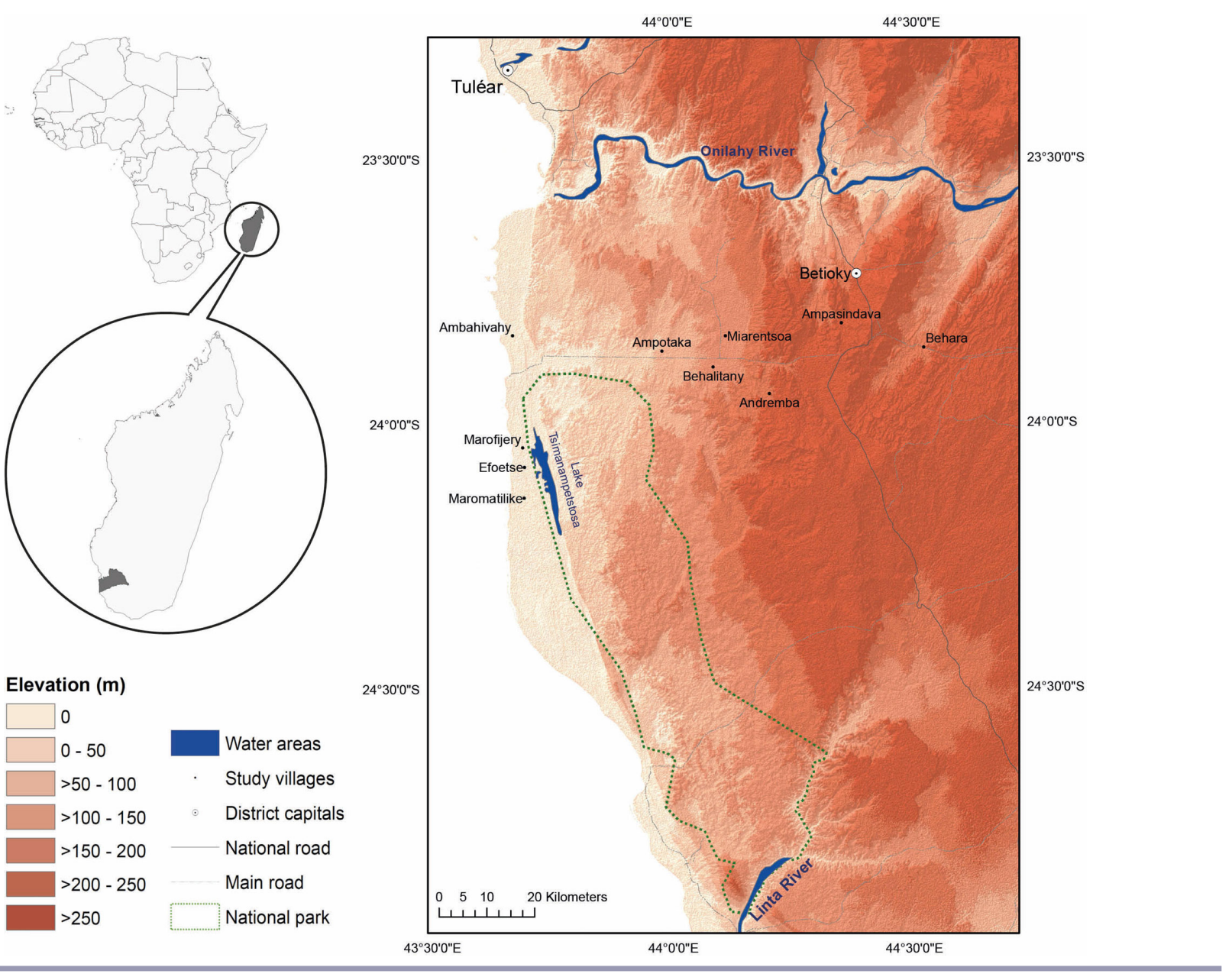

frequency of extreme weather events, including cyclones during the rainy season, have increased in southern Madagascar (Usman and Reason 2004, Tadross et al. 2008, Virah-Sawmy 2009, FAO and WFP 2014, WFP 2015b). The region was hit hard by cyclones Haruna in 2013 and Fundi in 2015; cyclones were previously uncommon in SW Madagascar (Tadross et al. 2008). Extreme weather events are predicted to increase further (Tadross et al. 2008).

\section{The political crisis in Madagascar}

Madagascar experienced a coupe d'état in 2009. As a result, the country was banned from the African Union and reprimanded by the European Union. Most international donors stopped support to the de facto Malagasy government. With foreign support making up $\sim 40 \%$ of all government spending, large parts of the economy and the provision of public services imploded (Ploch and Cook 2012, World Bank 2013). In southern Madagascar, social insecurity increased because of organized cattle raider groups (malaso; Feldt 2015, Götter 2016). Today, Madagascar has one of the highest levels of child malnutrition worldwide (WFP 2015a). Regular constitutional order of sorts was restored in 2014 but Madagascar still faces far more severe levels of poverty and undernourishment compared with before the political crisis (WFP 2015a, World Bank 2015a).

\section{Population pressure}

Madagascar's population quadrupled during the past 50 years (World Bank 2015b) and particularly in rural SW Madagascar population growth remains high (INSTAT 2011). In our study villages, the mean household size is $7.5 \mathrm{HH}$ members (see Table 1), and land scarcity is a severe agricultural constraint (Coral 2014). Because of the lack of agriculturally suitable land, slash-and-burn systems with long fallow periods are increasingly giving way (i) to short-cycle rotations with short fallowing periods and (ii) to continuous agriculture close to the villages (Coral 2014, Hanisch 2015).

\section{ANALYTICAL FRAMEWORK AND METHODS}

\section{Social-ecological traps}

To guide our analysis, we use a social-ecological traps (SET) approach (Enfors 2013, Boonstra and De Boer 2014). Several types of traps have been suggested, i.e., in the rural development literature (e.g., Barrett et al. 2008), in the ecological literature (e.g., Carpenter et al. 1999), as well as in the resilience literature (Carpenter and Brock 2008, Cinner 2011, Steneck et al. 2011, Enfors 2013). Specifically, SET are used to conceptualize the causal interplay of environmental degradation and livelihood impoverishment (Boonstra and De Boer 2014). SET refer to situations where 
feedbacks between social and ecological systems mutually reinforce each other, and lead toward unfavorable system states (Cinner 2011).

Table 1. Produced kilocalories (kcal) by household $(\mathrm{HH})$ in relation to $\mathrm{HH}$ size and minimum dietary energy requirements (MDER), $\mathrm{N}=140$. Total produced $\mathrm{kcal} / \mathrm{HH}$ is the sum of all $\mathrm{kcal}$ produced in 2014/HH. MDER is $1700 \mathrm{kcal} /$ day/person (FAO 2004), and was multiplied with the HH size and 365 days. The deficits (kcal) are the total kcal produced/HH/2014 minus the total MDER in $\mathrm{kcal} / \mathrm{HH} / 2014$.

\begin{tabular}{lcccc}
\hline \hline & Mean & $\begin{array}{c}\text { Standard } \\
\text { Error }\end{array}$ & Min & Max \\
\hline Household size & 7.5 & 0.3 & 1.0 & 30.0 \\
Total Kcal produced/ & $1,015,091$ & 225,538 & 0.0 & $2,4410,908$ \\
HH/2014 & & & & \\
Total MDER (in kcal)/ & $4,618,292$ & 170,313 & 620,500 & $11,789,500$ \\
HH/2014 & 21.4 & 3.8 & 0.0 & 393.4 \\
$\begin{array}{l}\text { Self-sufficiency (kcal in \%) } \\
\text { in 2014 }\end{array}$ & $-3,570,447$ & 26,0372 & $-11,715,308$ & $1,8205,908$ \\
Deficits (kcal) in 2014 & & & &
\end{tabular}

Poverty traps tend to describe the lock-in of people in poverty in a way that is a posteriori disconnected from ecosystems, and often describe traps as an exclusively socioeconomic problem (Barrett et al. 2008, Maru et al. 2012). Studies on poverty traps are criticized in disregarding important ecological parameters (Dasgupta 2007, Maru et al. 2012) as causal relations between both domains, i.e., rural poverty and environmental degradation, are not uncommon (Barrett et al. 2011, Sendzimir et al. 2011).

In contrast, SET analysis highlights interconnections between people and their natural environment, regarding them as elements of social-ecological systems (SES). Employing this variant of systems analysis (Sterman 2000), special emphasis is placed on key system variables, causal feedback loops, and external drivers (Cinner 2011, Sendzimir et al. 2011, Enfors 2013).

The CGIAR (Consultative Group on International Agriculture Research) Challenge Program on Water and Food (CPWF) applied a SET analysis to synthesize what they referred to as six problematic "resilience traps" (RT) based on more than 120 research projects globally (CPWF 2014). The RT relate to (1) high risk situations, (2) a high ratio between regional consumption and production, (3) variability that is difficult to deal with, (4) poor access to resources, (5) disenabling policy, and (6) cultural issues that may prevent change.

Table 2 describes the characteristics of the different traps, and lists the data sources that our analysis builds on. In this paper, we expand the thinking around these resilience traps, by proposing a set of hypotheses around (a) how they are formed in SW Madagascar, (b) how the different traps might interact to shape the observed lock-in dynamics, and (c) how they display a nested sort of character in the studied context.

\section{Systems analysis}

To assess likely causal relationships, we used systems analysis (Sterman 2000), particularly causal loop diagrams (CLD) on social-ecological interactions in the Mahafaly area. CLDs illustrate hypotheses about the structure of the relationships behind persistent poverty and environmental degradation in SW
Madagascar (cf. Sendzimir et al. 2011), pointing to the potential traps and mechanisms that both create and perpetuate them. However, in all CLDs, we differentiate between proven causal relationships, correlational relationships, and hypothesized relationships based on the evidence we find for the respective relationships.

Figure 2 consists of three CLDs. The first loop illustrates feedbacks between the production, risk, and variability trap based on our own data (Fig. 2, top), while the second loop ("policy trap") and the third loop ("production trap") are based on the references shown in Table 2 and in the discussion (Fig. 2, bottom). A separate CLD presented in Figure 3 illustrates the livelihood resources and insurance buffers that local farming households possess and use, based on our own data.

Fig. 2. A causal loop diagram exemplifying how external drivers interact with key system variables through feedback processes based on (i) causal, (ii) correlational, or (iii) hypothetical relationships. Plus and minus polarity arrows characterize relations between the different variables. + polarity signifies that both variables" values change in the same direction. " polarity indicates if one variable's value changes, the other one moves in the opposite direction. Inside a feedback loop, a variable may change because of an impact from outside (e.g., external driver) or because of changes of another variable inside the loop (Sendzimir et al. 2011).

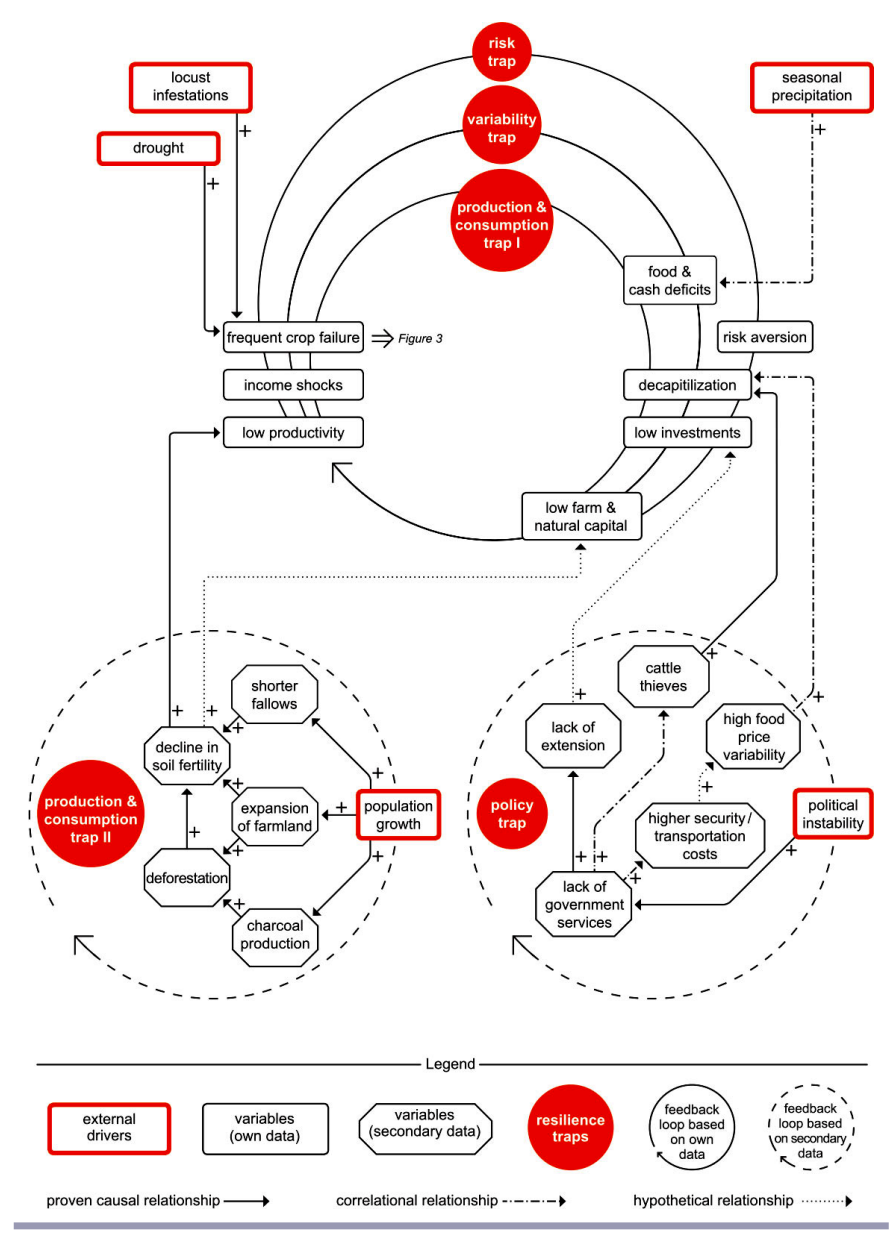


Table 2. Resilience traps (CPFW 2014) applied to southwestern Madagascar's Mahafaly region (cf. Barkmann et al. 2015)

\begin{tabular}{|c|c|c|}
\hline Resilience trap & Characterization & Source \\
\hline $\begin{array}{l}\text { a. Consumption/ } \\
\text { production traps }\end{array}$ & $\begin{array}{l}\text { The rate of consumption/outtake of bioresources is too close to or exceeds } \\
\text { the production rates leading to a vicious cycle of resource mining. }\end{array}$ & $\begin{array}{l}\text { Own data, Milleville et al. 2001, } \\
\text { Ratovonamana et al. 2013, Andriamparany } \\
\text { 2015, Hanisch 2015, Waeber et al. } 2015\end{array}$ \\
\hline b. Variability traps & $\begin{array}{l}\text { Small investments in agricultural farming systems do take place (resource } \\
\text { limitations make these very small). However, as risks manifest themselves } \\
\text { (recurrent droughts, insect invasions, cattle theft), investment failures } \\
\text { prevent the medium-term accumulation of capital as well as livelihood } \\
\text { improvements. }\end{array}$ & Own data \\
\hline c. Risk traps & $\begin{array}{l}\text { Because of multiple farming risks, incentives to invest in agricultural } \\
\text { farming systems are objectively low for smallholder farming households } \\
\text { (HH) who lack virtually any capacity to buffer income shocks. Local } \\
\text { households "learn" that investments are risky, further increasing their risk } \\
\text { aversion. }\end{array}$ & $\begin{array}{l}\text { Own data, Tadross et al. 2008, Hanisch et al. } \\
\text { 2013, FAO and WFP 2014, Hanisch } 2015\end{array}$ \\
\hline d. Policy traps & $\begin{array}{l}\text { Disenabling policies and lack of transparency prevents markets and } \\
\text { resources from being used effectively. }\end{array}$ & Ploch and Cook 2012, World Bank 2013 \\
\hline e. Resource access traps & $\begin{array}{l}\text { Most farming HHs have only very small plots of arable land and lack } \\
\text { access to irrigation water. Both limitations place a cap on agricultural per } \\
\text { HH income. }\end{array}$ & Own data \\
\hline f. Cultural traps & $\begin{array}{l}\text { Mindsets can prevent change. Although local people tend to respect } \\
\text { supernatural taboos, and social rural life is strongly influenced by } \\
\text { adherence to traditional cultural and clan values, farming decisions tend } \\
\text { to be fairly pragmatic given risks and resource constraints. }\end{array}$ & $\begin{array}{l}\text { Qualitative summary of personal } \\
\text { observations and informal, qualitative } \\
\text { interviews of the project team }\end{array}$ \\
\hline
\end{tabular}

Fig. 3. A causal loop diagram showing the insurance buffer/ livelihood resources that farming households make use of to cope with crop failures.

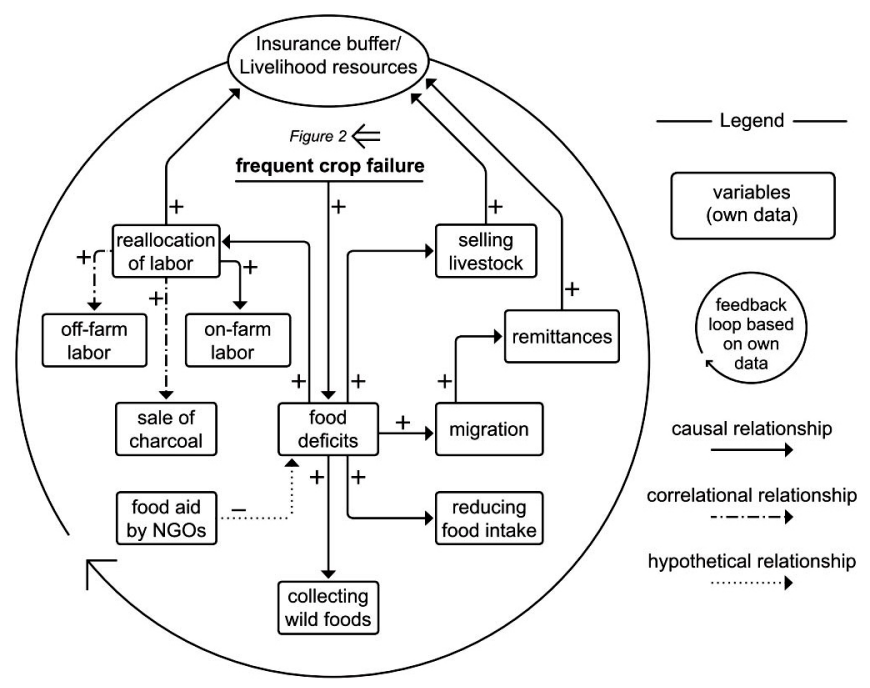

In the feedback loops, plus and minus polarity characterize relations between different variables. Inside the loop, a variable's value may change because of an impact from outside, e.g., an external driver, or because of changes in another variable's value (Sendzimir et al. 2011). We define a key system variable as a biophysical, political, social, or economic variable that plays an essential role in shaping the development trajectory of the SES if we can substantiate this role using recent local data or strong literature evidence. We regard the capacity to sustain $\mathrm{HH}$ food security, $\mathrm{HH}$ income, $\mathrm{HH}$ buffer/insurance, i.e., against drought and famine, and selected ecosystem services as key system variables. Important external drivers are defined as variables operating at different scales beyond the Mahafaly area that can influence key system variables considerably, such as rainfall patterns (cf. Enfors 2013).

\section{Field data collection}

The input data for the systems analysis comes from four primary sources:

1. high frequency longitudinal agro-economic survey to study $\mathrm{HH}$ cash income and expenditure chronologically,

2. recall survey to study $\mathrm{HH}$ coping strategies for food and cash deficits,

3. market participation survey to facilitate a value chain perspective on smallholder farming, and

4. an assessment of agricultural harvests from the households participating in (1) and (2) above.

\section{Longitudinal study of household incomes and expenditures}

To assess household incomes and expenditures, we conducted a longitudinal survey from the beginning of January 2014 to the end of December 2014 involving 150 systematically selected households. Of these $150 \mathrm{HHs}, 90 \mathrm{HHs}$ constitute a subsample of a baseline survey conducted in 2012 that included $934 \mathrm{HHs}$ from 24 villages (Neudert 2013, unpublished data). Households participating in the baseline survey were assigned to 6 clusters based on dominant livelihood strategies, e.g., agriculture, animal husbandry, use of natural resources, and nonagricultural income. Households from the fishing cluster were omitted because our focus was on farm households.

To diversify the set of agriculturally focused households interviewed, we added a cluster of "innovative" households that 
use more and/or other agricultural inputs than most households. The HHs of this cluster were drawn from a dedicated innovation survey conducted in 2012 and 2013 (Hänke and Barkmann, unpublished manuscript). Using stratified random sampling, 18 HHs were selected from Clusters 1-6 (excluding the fishing Cluster 3), and 60 innovative $\mathrm{HH}$ from Cluster 7. The resulting HHs stem from 11 Mahafalian villages (see Fig. 1). Ten of the $150 \mathrm{HHs}$ had migrated out of the study area, resulting in a total of 140 participating HHs. We applied sampling weights to adjust for the uneven sampling in the strata, and to be able to extrapolate our results to the total population in the study area (for details, see Appendix 2).

The parameters of the longitudinal survey included the following:

1. bought farm input (tools, fertilizer, pesticides, etc.)

2. crops bought and sold

3. livestock bought and sold

4. cash income from and expenditure for on-farm labor

5. cultural expenditures and income (e.g., zebus for funerals, sacrifices, presents, etc.)

6. nonfarm income in cash (industry, mining, tourism, handicrafts)

7. cash expenditures for and income from medicine and education

8. cash expenditures for and income from alcohol, cigarettes, coffee, batteries, etc.

9. money sent to and received by (external) family members

We asked respondents to keep daily diaries of the above activities, purchases, and spending. In the project region, $73 \%$ of the population $>18$ years old is illiterate (Neudert et al. 2015). Therefore, we used pictograms (Wiseman et al. 2005; see Appendix 3) to support the written explanations in the daily record sheets that we provided. Every week, a team of two trained research assistants visited each respondent $\mathrm{HH}$ to support record keeping, and to collect report sheets.

After a training and piloting period of four weeks, including feedback workshops to fine tune survey administration, data collection for the longitudinal survey started. Participating HHs were formally contracted, and received a remuneration of 5000 ariary per month (1.6€, for comparison $=7 \mathrm{~kg}$ of cassava or a small chicken). Thus, participating households were slightly better off than nonparticipating households because the remuneration included an incentive component in addition to offsetting the labor needed to keep the record sheets. After quality control, data were entered into a Microsoft ACCESS database.

\section{Recall survey of coping strategies}

To complement the longitudinal study, we conducted a recall survey with all 140 respondent households covering the 12-month period of the longitudinal survey. The recall survey focused on strategies to cope with food shortages, including migration of $\mathrm{HH}$ members, changes in livestock holdings, collection of wild food, borrowing of money, as well as food aid received.
Market participation survey

To complement the farm-centered perspective of the longitudinal and the recall survey, an additional survey on market participation was conducted. The market participation survey provided a value chain perspective on smallholder farming (M4P 2006, Mitchell and Coles 2011). Because we were interested in general trends and mechanisms of market participation, a mix of quota sampling and spatial sampling was conducted targeting commercially active farmers $(n=64)$ as well as local traders $(n=56$; for details, see Coral 2014). Following guidelines by M4P (2006), we sought to analyze how seasonal cash constraints relate to farming activities and food availability.

Assessment of agricultural harvests and food self-sufficiency To understand the extent to which households were self-sufficient, we measured agricultural yields of households participating in the longitudinal survey. All yields are reported in dry-matter kilograms $\left(\mathrm{kg}_{\mathrm{DM}}\right)$ per crop, and summed up over all arable plots per HH. Our assistants accompanied HH members to their fields during the harvest season. Field margins were mapped using GPS tracking to determine field sizes (in ha; $n=358$ ). Raw yields were measured in situ directly after harvest by our assistants using field scales in $\sim 70 \%$ of all yield data points. Dry matter was determined through oven drying at $65^{\circ} \mathrm{C}$, and wet/dry mass conversion factors were calculated (Hanisch 2015, see Appendix 4) to calculate $\mathrm{kg}_{\mathrm{DM}}$. In addition, shell-seed proportion factors by Hanisch (2015) were applied to beans, millet, and sorghum.

We also recorded yield estimates of farmers in local units (oxcarts, sacks of rice, baskets, and of tin cans originally containing 100 $\mathrm{ml}$ of condensed milk: kapoky). These yield estimates were compared to direct measurements, and averaged to calculate conversion factors from local units to $\mathrm{kg}_{\mathrm{DM}}$ (see Appendix 4). The conversion factors were used for the $\sim 30 \%$ of cases where we could not determine the harvest ourselves in situ. We then converted all harvest data into kilocalories (kcal) to estimate food selfsufficiency based on arable crop harvests. Food exchanged for labor or obtained from self-raised animal sources is not included, however.

We calculated minimum dietary energy requirements (MDER) per $\mathrm{HH}$ to estimate undernourishment (FAO 2004). Human dietary energy requirements differ by gender, age, body mass index, and levels of physical activity (FAO 2008). Taking national population statistics into account, FAO (2004) published weighted MDER averages for Madagascar, expressed as kilocalories ( $\mathrm{kcal})$ per person per day $(1700 \mathrm{kcal} /$ person/day). To estimate the MDER/HH/2014 for our sampled households, 1700 kcal was multiplied with the number of $\mathrm{HH}$ members times 365 days. To finally calculate the percentage of food self-sufficiency per $\mathrm{HH}$, the $\mathrm{MDER} / \mathrm{HH} / 2014$ was compared to the total produced $\mathrm{kcal} / \mathrm{HH}$ in 2014.

\section{Influence of rainfall on harvests (regression analysis)}

To illustrate the influence of rainfall on harvests, we regressed total harvest per $\mathrm{HH}(\mathrm{kg} /$ year 2014) on age and years of schooling of the household head, total planted area (ha), rainfall ( $\mathrm{mm} /$ year 2014; CNA 2015), and the occurrences of dry spells ( $>7$ days without rainfall in the rainy season January-May 2014 [Hanisch 2015]; see Appendix 5). 
Table 3. Harvest overview from the 2013/2014 cropping season, $N=140$. Source: harvest survey and longitudinal survey. 1 kilocalories (kcal) for individual crops were converted through datasets from USDA ARS (2015). HH = household.

\begin{tabular}{|c|c|c|c|c|c|c|c|c|c|c|}
\hline \multirow[b]{2}{*}{ Crop } & \multirow[b]{2}{*}{$\mathrm{N}$} & \multirow[b]{2}{*}{$\%$ of $\mathrm{HHs}$} & \multicolumn{4}{|c|}{ Crop yield $(\mathrm{kg} / \mathrm{HH})$} & \multicolumn{4}{|c|}{$\mathrm{Kcal}^{1}$} \\
\hline & & & Mean & S. E. & Min & Max & Mean & S.E. & Min & Max \\
\hline Cassava & 139 & 99.3 & 375.3 & 102.6 & 0 & $11,230.4$ & 600,411 & 164,137 & 0 & $17,968,656$ \\
\hline Cowpea & 134 & 95.7 & 35.9 & 8.1 & 0 & 719.5 & 29,050 & 6584 & 0 & 582,799 \\
\hline Maize & 112 & 80.0 & 18.7 & 4.8 & 0 & 558.8 & 68,183 & 17,673 & 0 & $2,039,748$ \\
\hline Millet & 43 & 30.7 & 14.6 & 5.1 & 0 & 476.6 & 55,189 & 19,357 & 0 & $1,801,603$ \\
\hline Mung beans & 119 & 85.0 & 22.8 & 3.7 & 0 & 287.6 & 78,245 & 12,815 & 0 & 986,510 \\
\hline Sorghum & 31 & 22.1 & 9.1 & 6.0 & 0 & 844.6 & 30,050 & 19,866 & 0 & $2,778,755$ \\
\hline
\end{tabular}

\section{RESULTS}

Agricultural production (arable crops) and household selfsufficiency in 2014

HHs have average land holdings of $2.6 \pm 0.2$ ha distributed over $2.4 \pm 0.1$ plots (mean $\pm 1 \mathrm{SE}$, own field measurements). The agroeconomic survey revealed that close to $75 \%$ of the total cultivated area is used for four main agricultural products: cassava (Manihot esculenta), maize (Zea mays), cowpeas (Vigna unguiculata), and mung beans (Vigna radiata). Farmers generally grow cassava and sweet potato (Ipomoea batatas) as continuous crops, often intercropped with beans or peas on old fields with low soil fertility. Fields recently cleared by slash-and-burn are commonly used for annual crops such as maize, millet (Pennisetum glaucum), sorghum (Sorghum bicolor), and different pulses.

The year 2014, when this study was conducted, was particularly poor in terms of rainfall. Total annual precipitation for the Mahafaly region varied between $175 \mathrm{~mm}$ (littoral, west) and 500 mm (plateau, east; CNA 2015, see Appendix 1). Annual rainfall was a significant predictor of total harvest $/ \mathrm{HH}(\mathrm{p}=0.02)$ as well as the occurrence of dry spells $(p=0.05$, linear regression, see Appendix 5). Consequently, agricultural harvests were low and consisted largely of the relatively drought resistant cassava. The on-farm yield assessment showed that the cassava harvest averaged at $375 \mathrm{~kg}$ per $\mathrm{HH}$ (Table 3). Maize yield was exceptionally low (mean: $<20 \mathrm{~kg} / \mathrm{HH}$ ) because of locust invasions that destroyed most maize plots. Harvests of legumes averaged between 23 and $36 \mathrm{~kg}$ per $\mathrm{HH}$ (if grown), but the variance was large. Households in the littoral that grew millet and sorghum experienced a complete crop failure, and harvested only $10-15 \mathrm{~kg}$ of these crops on average.

Converting our own harvest measurements from $\mathrm{kg}$ into kcal (see Table 1), we found that HHs produced, on average, only $21 \%$ of their minimum dietary energy requirements by agriculture (MDER). Eighty percent of all HHs produced $<25 \%$ of their MDER, $\sim 11 \%$ produced $25-50 \%, \sim 6 \%$ produced $50-100 \%$, and only $\sim 4 \%$ more than $100 \%$.

\section{Seasonality of food availability and cash flows}

Annual crops were harvested from March to May, and cassava in July and August (see Appendix 6). In the market participation survey, the majority of farmers reported that they had enough food from April to October, whereas they reported food shortage from mid-October to end of March (Fig. 4a, market participation survey). Trailing harvest periods closely, cash expenditures for food decreased from March to May and from August to
September (Fig. 4b, longitudinal survey). One to two months after the cassava harvest, food expenditures began to increase steadily reaching their maximum from November to March.

Most respondents stated that they were cash constrained throughout roughly half the year; $30 \%$ of respondents stated, however, that they were cash constrained during the whole year. Reported cash constraints and food self-sufficiency were closely correlated (Fig. 4a, Spearman: $r=0.98, \mathrm{p}=<0.01$ ).

The longitudinal survey revealed that HHs earned $23 €$ from crop sales in 2014, but spent more than 10 times that for food purchases (250€ on average). Given that most HHs lack cash savings, farm households had to use a range of nonfarm income sources to cope with this situation (see below). Also, the correlation between chronological food expenditures and nonfarm income is substantial (Spearman, $r=0.63, p=<0.01$, see Fig. 4b).

\section{Strategies to deal with food and cash shortages}

Farmers used a range of nonfarm income sources, such as wage labor, charcoal production, trade, and handicrafts to cope with food and cash shortages (recall survey). The far most important strategy was to sell livestock, primarily zebus and goats (recall survey), accounting for $56 \%$ of all $\mathrm{HH}$ cash income in 2014. Likewise, there was a strong correlation between chronological food expenditures and income generated from livestock (Spearman, $r=0.54, p=<0.01$, longitudinal survey). Remittances from emigrated $\mathrm{HH}$ members, mostly residing in urban areas, were the second most important cash income source (Fig. 5a). Twelve percent of all HHs had at least one family member who emigrated (temporarily) in the lean period, however, $7 \%$ of $\mathrm{HH}$ emigrated completely in 2014.

More than $80 \%$ of $\mathrm{HHs}$ collected wild food (see Fig. 5b), particularly fruit of the prickly pear cactus (Opuntia spp.) and yam roots (Dioscorea spp.). A large proportion of all HHs (> $70 \%$ ) also received food aid by NGOs, predominantly through food-for-work programs.

Almost half of the HHs reported that they reduced food intake for adults; $36 \%$ reduced food intake also for children. Forty percent of the surveyed HHs borrowed money from informal credit networks consisting mainly of family members or neighbors. Most widespread was credit for seeds. If prompted to comment on formal credit institutions found in the nearby towns of Betioky and Tuléar, farmers mentioned a lack of effective access to and lack of trust in these institutions. 
Fig. 4. (a) Cash constraints and food availability based on market participation survey; (b) Average food income, expenditure, and nonfarm income in 2014, sampling weights applied, $1 €=3337$ ariary on average for 2014 (https://www.oanda.com/). Data shown as sums for every four weeks from the longitudinal survey. $\mathrm{N}=140$.
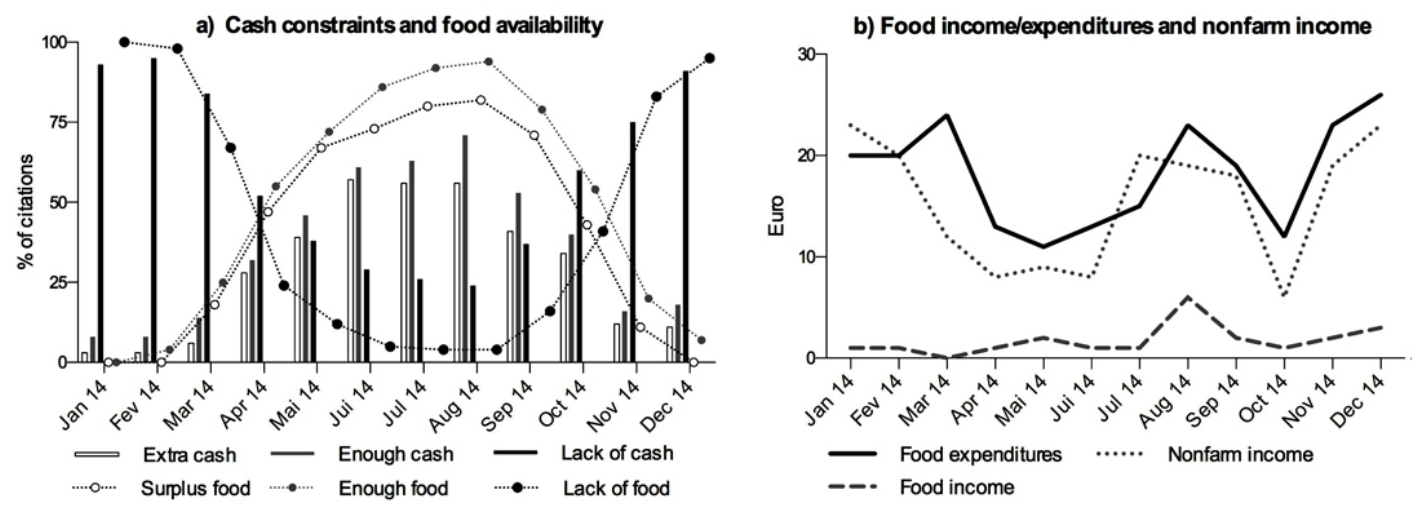

Fig. 5. (a) Average noncrop cash income sources per $\mathrm{HH}$ in 2014, sampling weights applied (see Methods), $\mathrm{N}=140$, Source: longitudinal survey. $1 €=3337$ ariary on average for 2014 (https://www.oanda.com/). †Other is mainly the sale of wild plants, mangos, and straw for construction material; $\$$ customs mainly presents cash received through traditional sociocultural events (ceremonies, sacrifices, marriages, births, etc., Malagasy: lilin-draza or fombaamam-panao). (b) \% of $\mathrm{HH}$ that adopted coping strategies, sampling weights applied (see Methods), $\mathrm{N}=140$, Source: recall survey (a) refers to adults, (c) refers to children.
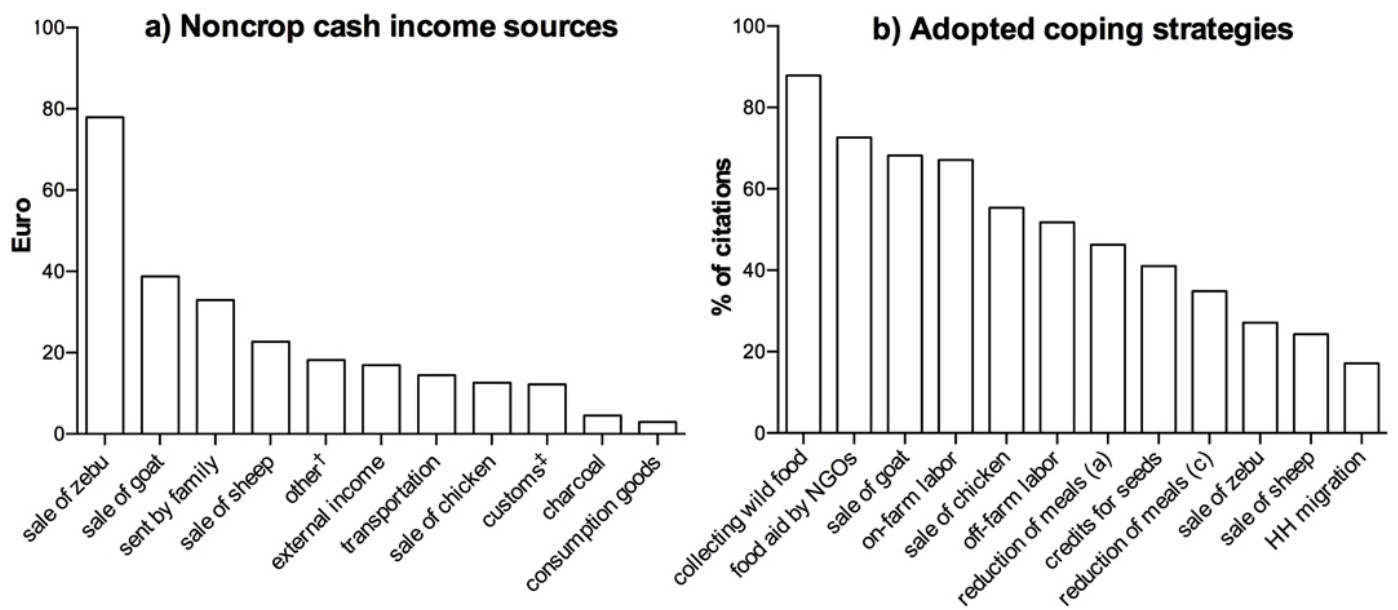

\section{DISCUSSION}

We analyze the original data described above using causal loop diagrams to reveal a set of interacting and partly nested socialecological traps. Figures 2 and 3 highlight the most relevant aspects of this integration. We find evidence for several causal relationships, however, some relationships are based on statistically significant correlations, and others are rather hypothetical. Yet, we find strong evidence for the existence of four out of the six proposed resilience traps, and some evidence for the two remaining ones. Further, we find that the traps interact, and that the production and consumption trap, the variability trap, and the risk trap also form a nested set of traps.

\section{Resource consumption/production traps}

A consumption/production trap occurs when the rate of consumption/outtake of natural resources is too close to or above the actual rate of production (CPWF 2014). Forty-five percent of the regional forest has been lost over the past 40 years (Brinkmann et al. 2014; Fig. 2, bottom-left). Fallow periods have also been substantially shortened over time, giving way to 
continuous cropping. In fact, from 358 arable plots belonging to the surveyed $140 \mathrm{HHs}$, fallowing was only practiced in $6 \%$ of all fields during the past 20 years (recall survey; Fig. 2, bottom-left). Soils of arable land have significantly lower soil fertility compared with soils of rangelands and forests in the Mahafalian area indicating nutrient mining. After converting regional forest to maize fields through slash-and-burn, Milleville et al. (2001) found a decrease of $60 \%$ in available phosphorus, $55 \%$ in nitrogen, $44 \%$ in carbon, and $27 \%$ in potassium after 5 years in the region. Moreover, an increase in soil density was observed, which reduces the infiltration capacity for rain (Milleville et al. 2001). Simultaneously, maize yields declined from $2 \mathrm{tha}^{-1}$ in the first year to less than $0.5 \mathrm{t} \mathrm{ha}^{-1}$ after five years (Milleville and Blanc-Pamard 2001). Thus, there is substantial evidence that the utilized slashand-burn farming system (hatsaky) is not sustainable in terms of a long-term balance of inputs and outputs, i.e., outtake is above sustainable production rates at current (Fig. 2, bottom-left).

In our longitudinal survey dataset, we found a significant correlation between income generated from selling livestock and expenditures for food (Spearman, $\mathrm{r}=0.54, \mathrm{p}=<0.01$ ) whereas the recall survey provided complimentary evidence for a causal relationship, i.e., that farmers rely heavily on revenues from selling livestock to cope with cash and food deficits (Fig. 3, top-right). But livestock herding tends to degrade the remaining forests (Ratovonamana et al. 2013) also indicating outtake above production rates particularly in the littoral of the Mahafaly area (Feldt 2015, Götter et al. 2015).

Although woody biomass collected in the forest is the only local fuel source, many urban areas in western Madagascar are also supplied by wood and charcoal from the dry spiny forests of the region (Dirac et al. 2006). Indeed, we found charcoal making to be a widespread strategy employed by farmers to cope with cash deficits (longitudinal survey; Fig. 3, middle-left). Thus, the extent of forest cover as well as forest ecosystem quality from a biodiversity conservation point of view continues to be under pressure. The loss of forest has, in turn, negative consequences on food security, as the habitat for wild plants, particularly wild yams, is lost, which are frequently collected when farmers face periods of food shortage (Andriamparany 2015).

In sum, certain key resources are extracted at a higher rate than they are replenished. That is, key aspects of the system are in a "resource mining cycle" (CPWF 2014), which both threatens the current production capacity of the Mahafalian agro-ecosystem (Fig. 2, left), as well as the unique forest biodiversity of the region (Ganzhorn et al. 2001, Waeber et al. 2015). We conclude that there are multiple lines of evidence for the existence of a production/ consumption trap.

\section{Variability traps}

In a variability trap, small investments into agriculture do take place, but large variability of external conditions leads to frequent investment failures. Thus, many investments do not lead to longterm improvement of farm capital and/or livelihoods.

The high variability of environmental conditions, particularly rainfall in the research region results in frequent crop failures, particularly of the cash crops maize and beans (Fig. 2, top-left). This hinders capital accumulation, and in turn, places a cap on $\mathrm{HH}$ capacity to invest further in agriculture contributing to a selfreinforcing feedback loop (Fig. 2, middle-right).
Furthermore, capital accumulation is hindered by the seasonally recurring need for food purchases that furthermore drain capital from HHs. As soon as harvests are in, educational fees for children are due, and important socio-cultural events, e.g., festivals for harvest, the rain gods, and the ancestors, result in costs that even poor households need to bear if they wish to maintain good social standing (longitudinal and recall survey). Besides, loans have to be repaid, either in cash or in food (longitudinal and recall survey).

From February to April, the hottest and wettest months, various tropical diseases occur regularly in the region, e.g., hepatitis, typhus, diarrheal diseases, and occasionally malaria (UNICEF 2013), resulting in considerable health expenditures (longitudinal data). The reduction in food intake (Fig. 5b) further increases vulnerability to such diseases, particularly for children (Johansson 2010, UNICEF 2013). In turn, disease and undernourishment most likely constrain agricultural productivity, and hence selfreinforce low farm outputs.

Even if there is no particular pressing need in some households for spending in the above categories, postharvest is the only time when resources are available at all to fulfill postponed desires for household- and consumption goods. As a consequence, many households sell their crops immediately after harvest (longitudinal data; Manon 2014). At that time, however, food prices are low with many sellers in the market. In contrast, prices increase dramatically during the lean period (market participation survey), particularly after droughts and crop failures in southern Madagascar (WFP 2015a). Similarly, when HHs sell livestock to purchase food staples, animal prices tend to be lower because many HHs sell livestock at the same time (recall survey data; Fig. 3, top-right).

Because of the need to use income from livestock sales to offset food shortages during several months of the year, $\mathrm{HH}$ assets are regularly depleted, and accumulation of capital is hindered. This is self-reinforcing feedback often characterized in the literature as a typical poverty trap (e.g., Carter 2007, Barrett 2008, Carter and Lybbert 2012). Overall, the variability-induced shocks in food production make it very difficult for households to save enough capital to invest in more profitable agricultural activities. Thus, the direct effect of the variability trap results in both low yields (Fig. 2, left) and low adaptive capacity to overcome low yields. This represents a further self-reinforcing feedback, which essentially perpetuates the trap dynamics.

\section{Risk traps}

A risk trap can occur when high-risk situations reduce internal incentives to invest in agricultural systems (CPWF 2014). Agricultural risks are manifold in the Mahafaly region. Even in good years, rainfall is low, with precipitation in the littoral close to the threshold for any agricultural production (Kaufmann 2004). In addition, poorly distributed rains (dry spells) during the rainy season, locust invasions, and cyclones, all of which manifested themselves in the regional cropping season 2013/2014 (FAO and WFP 2014, Hanisch 2015), pose substantial additional risks.

Historically, there are reports of good harvests in the 1980s and 1990s when large volumes of maize were exported from SW Madagascar to the neighboring French island of La Réunion (Klein et al. 2008, Minten et al. 2010). Thus, rather than being a 
region completely unsuitable for agriculture, the Mahafaly Region is an area where existing patterns of environmental variability make agriculture a high-risk business facing multiple uncertainties. Obviously, this high-risk environment further reduces the incentives of risk-averse smallholders to invest in agriculture, even if the expected value of certain investments was positive in the long run.

Under these conditions, households may profit from a diversification strategy with respect to household income, particularly from a food security perspective, compared with a focus on investments in arable agriculture only. The households investigated relied largely on a mixed land use system in which animal husbandry plays a crucial insurance function (for a more detailed analysis, see Hänke and Barkmann 2017). As the fundamentally risky farming environment suggests, direct investment in agriculture is limited because input levels of fertilizer, plant protection agents, machinery, tools, and herding equipment is extremely low (longitudinal survey; see also Coral 2014, Feldt 2015, Hanisch 2015). Local, noncertified seeds for annual cash crops (maize, legumes) are the only major agricultural input that is being purchased, and which is only used on the most fertile fields (recall survey).

Households are reluctant to invest more because investments may fail. The observed lack of investments can, thus, be characterized as a risk trap, and this kind of risk aversion (Wolgin 1975, Eakin 2000) notoriously affects farm yields negatively, and also contributes to the production trap identified above (Fig.2, middleright).

In sum, the extremely low agricultural investments seen in the Mahafaly region appear as a result of the interaction between the risk trap and the variability trap (Fig. 2). Further traps contribute to the apparent lock-in, however see following subsections.

\section{Policy traps}

Policy traps occur when disenabling policies and lack of transparency hinder investment because markets and resources are prevented from being used effectively (CPWF 2014). As a direct consequence of the coupe d'état in 2009, most international donors stopped their support to the Malagasy government. Consequently, regional governmental services collapsed, including the public education and health systems, maintenance of infrastructure, public safety, and agricultural extension (World Bank 2013). The case of the public security sector illustrates the cascading effect of the crisis, as zebu keeping has become a highly risky activity in southern Madagascar because of cattle raiders (malaso; Feldt 2015, Götter 2016). Although small-scale cattle theft has certain roots in traditional southern Malagasy customs (Hoerner 1982, Fauroux 1989), more aggressive malaso groups used the collapse of the public safety system in southern Madagascar to arm themselves and turn to organized crime (Fig. 2, bottom-right). The malaso do not only attack herding households, however. These days, traders regularly have to pay "security fees" to travel safely to the marketplaces in the region (Coral 2014), which in turn results in higher food prices for the local population (Fig. 2, bottom-right). Another example is the antilocust campaign (2013-2016) developed by the FAO that did not receive full funding. As a consequence, uncontrolled locust populations developed and spread in 2013 (FAO 2013). Locusts destroyed $\sim 80 \%$ of the maize yield of the farmers sampled in this study, illustrating the country's low capacity to deal with such crises. Clearly, the policy trap has made the country less resistant to shocks, such as droughts, cyclones, and insect infestations (World Bank 2013), reinforcing feedbacks as shown in Figure 2. Furthermore, reduced and/or more expensive market access aggravates the seasonal price peaks in the area, and makes external inputs more expensive, most likely reinforcing the risk and the variability trap. Although these constraints occur at multiple levels, i.e., national, regional, and local, they are interdependent, exemplifying what Barrett and Swallow (2006) have referred to as a fractal poverty trap.

\section{Resource access traps and cultural traps}

Resource traps refer to situations in which access to resources, such as land, put a cap on revenues despite high productivity (CPWF 2014). In that exact sense, resource traps are not a major issue in the Mahafaly region; we suggest that productivity is so low that the conditions for the resource trap are not met. However, it is the lack of access to fertile land and particularly the lack of rainfall and/or easily accessible irrigation water that fundamentally prevent higher productivity. From an agronomic point of view, water is probably the most limiting factor in SW Madagascar (Hanisch 2015). If more water became available, prospects for regional agriculture would brighten substantially. Unfortunately, current climate change predictions do not point to an imminent improvement of the situation; instead, the current high frequency of droughts seems to indicate a worsening trend (Tadross et al. 2008).

Many farming HHs report that labor availability is a major constraint to enlarging their plots (Coral 2014), particularly since weeding is labor intensive (longitudinal data). Given the lack of high quality land and effective access to irrigation water as well as the high investment risks in agriculture, lack of labor appears to be a result of low productivity rather than as its cause.

Cultural traps refer to situations in which mindsets prevent beneficial change (CPWF 2014). Although the overall socioeconomic situation appears bleak, it was clear from the recall survey as well as from a number of personal communications that many smallholder farmers and small traders in the Mahafaly region are willing to take advantage of attractive production and business opportunities. In comparison to the traps discussed above, the impact of the specific cultural traps therefore appears low. A potential exemption may be cultural traditions that command even poor households to spend substantial resources on a number of customs.

\section{Synthesis: evidence for resilience traps}

We found evidence for four of the six resilience traps, and some evidence for the additional two. We suggest that the production and consumption trap, the variability trap, and the risk trap form a nested set of traps. Agricultural risks are so large and environmental conditions so variable, that farmers are risk-averse and invest little into farming systems. That is, even in good years, agricultural production remains low. These traps, however, also interact with the policy trap, which operates at a higher organizational level. To a certain degree, the frequent crop failures that form a central element of the nested traps are buffered, particularly by the sale of livestock, international food aid, or offfarm labor (see Fig. 3). On the other hand, effects of the policy trap result in higher and more variable food and transport prices, 
and in an unfavorable climate for external long-term and/or commercial investments (World Bank 2015c).

\section{CONCLUSION}

In sum, a set of different interacting mechanisms related to the ratio between resource consumption and production, to risk and variability, and to disenabling policy, create a set of partly selfreinforcing, social-ecological traps in the region, which tend to perpetuate low agricultural yields, grossly insufficient livelihoods, and ongoing environmental degradation of this unique environment. Specifically, we found that the risk trap, the variability trap, and the production and consumption traps form a nested set of traps. Although the extremely low agricultural investments by farmers appear as a result of the interaction between the risk and the variability traps, the production trap is nested in both. Consequently, local farmers remain risk-averse and invest little into farming systems keeping farm yields notoriously low. HH's assets are largely based on natural resources, livestock being by far the most important in 2014. Poor education levels and limited skills severely limit high-return household income diversification. Although interventions are certainly needed to counter and compensate for the lack of food and cash that a large share of the households experience during many months every year, investments in the agricultural sector do not appear to be an ideal solution. And indeed, the only "balancing" feedback we found in our systems analysis was associated with off-farm employment (Fig. 3). Agricultural activities are only seasonally feasible and highly risky. Climate change projections for the broader region show an increase in extreme weather events such as cyclones, prolonged droughts, and dry spells (Tadross et al. 2008), suggesting that rain-fed farming has become, and will become even more difficult in the future. Despite this fact, a large number of donors and NGOs present in the region almost exclusively run agricultural food-for-work programs. In these programs, maize was by far the most often promoted crop in 2014 (recall survey data). However, we found that locusts destroyed $\sim 80 \%$ of the maize harvest in 2014 . In addition, maize is one of the major drivers of deforestation in southern Madagascar (Réau 2002, Minten et al. 2010). This clearly shows that current development agendas suffer from a too limited view of how contemporary social-ecological systems on the Mahafaly Plateau operate. At best, today's development efforts serve as smaller adaptations along existing, highly unsustainable, development pathways. However, what really is needed are efforts that fundamentally alter current socialecological interactions, and that have the capacity to break the identified traps. We conclude that a better diagnostic to the complex problems at hand, guided by a sound social-ecological systems perspective, is a necessary first step toward that. Based on our analysis, we identify four issues that need to be addressed to escape the current situation in the Mahafaly region:

1. Generate support for income sources outside the current farm/livestock sector in order to (i) reduce the pressure on the unique Mahafalian biodiversity and (ii) better hedge the risks of local rain-fed agriculture. These income sources should particularly generate benefits during the lean season, and also have a low environmental impact. Examples include small-scale poultry farming in cooperatives, yam root domestication (Hänke et al. 2014) and production of Opuntia spp. seed oil (Hänke 2016).
2. A decent road might enhance market access (Coral 2014). However, as we saw, few farming HHs produced any crop surpluses. In the long term, however, better infrastructure might increase off-farm income opportunities (cf. Barrett 2008).

3. Coordinate simultaneous investments across multiple scales (cf. Enfors 2013, Mikulcak et al. 2015), in, e.g., agricultural improvements, markets, infrastructure, health, and extension services. As we saw, hunger, poverty, and environmental degradation are closely linked.

4. Promote opportunities for access to credit, capital, and insurance (cf. Barrett et al. 2008, Hanjra et al. 2009) to effectively deal with the risk and variability traps.

The social-ecological system analysis we conducted provides new insights on causal and correlational relationships between poverty and environmental degradation in the Mahafaly region. In addition, we identified a number of hypothetical relationships that would be worth studying further. As Scales (2014:10) concluded, "conservation and development needs a new paradigm in Madagascar." Our study suggests that environmental degradation, poverty, and hunger are closely linked, and that these challenges should, therefore, be addressed simultaneously. A major development challenge in the Mahafaly region is to move beyond the prevailing focus on "coping," and instead identify trajectories where both local livelihoods and the region's unique biodiversity can thrive in the long term, and deliberately navigate a transformation toward those.

Responses to this article can be read online at: http://www.ecologyandsociety.org/issues/responses. $\mathrm{php} / 9130$

\section{Acknowledgments:}

First of all, we want thank all participating households in this study. Likewise, we want to thank our assistants, namely Jaonalison Henitsoa, Fernando Heritiana, Laurent Ravelo, Nadia Saheliarilala, Bakoly Tiddiana, and Dieu-Donné Faralahy. We are also grateful to Hugo Bertram Rohrbeck for graphical support in Figures 1, 2, \& 3 and two anonymous reviewers who helped to improve the paper. This research was possible because of generous funding by the German research ministry (BMBF) through the Sustainable Land Management Program, specifically the SuLaMa project (Sustainable land management in southwestern Madagascar).

\section{LITERATURE CITED}

Andriamparany, J. N. 2015. Diversity, local uses and availability of medicinal plants and wild yams in the Mahafaly region of southwestern Madagascar. Dissertation. University of Kassel, Witzenhausen, Germany. [online] URL: https://kobra.bibliothek. uni-kassel.de/bitstream/urn:nbn:de:hebis:34-2015083148986/3/ DissertationJessicaNAndriamparany.pdf

Andriamparany, J. N., K. Brinkmann, V. Jeannoda, and A. Buerkert. 2014. Effects of socio-economic household 
characteristics on traditional knowledge and usage of wild yams and medicinal plants in the Mahafaly region of south-western Madagascar. Journal of Ethnobiology and Ethnomedicine 10 (1):1-21. [online] URL: https://ethnobiomed.biomedcentral.com/ articles/10.1186/1746-4269-10-82 http://dx.doi.org/10.1186/1746-4269-10-82

Barkmann, J., H. Hänke, S. Hanisch, and T. Feldt. 2015. Sticking to the digging stick: resilience traps perpetuate poverty in southwestern Madagascar's Mahafaly Region. In G. Gerold, editor. Deutscher Kongress für Geographie 2015, Fachsitzung: LNFS-13. Humboldt University of Berlin, Germany.

Barrett, C. B. 2008. Poverty traps and resource dynamics in smallholder agrarian systems. Pages 17-40 in A. Ruijs and R. Dellink, editors. Economics of poverty, environment, and natural resource use. Springer, Wageningen, The Netherlands.

Barrett, C. B., M. R. Carter, and M. Ikegami. 2008. Poverty traps and social protection. Worldbank, Washington, D.C., USA. [online]URL: http://siteresources.worldbank.org/SOCIALPROTECTION/ $\underline{\text { Resources/SP-Discussion-papers/Social-Protection-General-DP/0804. }}$ pdf http://dx.doi.org/10.2139/ssrn.1141881

Barrett, C. B., and B. M. Swallow. 2006. Fractal poverty traps. World Development 34(1):1-15. http://dx.doi.org/10.1016/j. worlddev.2005.06.008

Barrett, C. B., A. J. Travis, and P. Dasgupta. 2011. On biodiversity conservation and poverty traps. Proceedings of the National Academy of Sciences of the United States of America 108 (34):13907-13912. http://dx.doi.org/10.1073/pnas.1011521108

Barron, J., J. Rockström, F. Gichuki, and N. Hatibu. 2003. Dry spell analysis and maize yields for two semi-arid locations in east Africa. Agricultural and Forest Meteorology 117(1-2):23-37. http://dx.doi.org/10.1016/S0168-1923(03)00037-6

Bayala, J., Z. Bourama, H. van der Hoek, R. Lamsellek, and M. Nouatin, and G. Randrianarisoa. 1998. Quelle recherche pour le développement des zones marginales de la region Sud-Ouest de Madagascar. FOFIFA, Antananarivo, Madagascar.

Boonstra, W. J., and F. W. De Boer. 2014. The historical dynamics of social-ecological traps. Ambio 43(3):260-274. http://dx.doi. org/10.1007/s13280-013-0419-1

Brinkmann, K., F. Noromiarilanto, R. Y. Ratovonamana, and A. Buerkert. 2014. Deforestation processes in south-western Madagascar over the past 40 years: What can we learn from settlement characteristics? Agriculture, Ecosystems \& Environment 195(1):231-243. http://dx.doi.org/10.1016/j.agee.2014.06.008

Carpenter, S. R., and W. A. Brock. 2008. Adaptive capacity and traps. Ecology and Society 13(2):40. http://dx.doi.org/10.5751/ es-02716-130240

Carpenter, S. R., D. Ludwig, and W. A. Brock. 1999. Management of eutrophication for lakes subject to potentially irreversible change. Ecological Applications 9(3):751-771. http://dx.doi. org/10.2307/2641327

Carter, M. R. 2007. Poverty traps and natural disasters in Ethiopia and Honduras. World Development 35(5):835-856. http://dx.doi. org/10.1016/j.worlddev.2006.09.010
Carter, M. R., and T. J. Lybbert. 2012. Consumption versus asset smoothing: testing the implications of poverty trap theory in Burkina Faso. Journal of Development Economics 99(2):255-264. http://dx.doi.org/10.1016/j.jdeveco.2012.02.003

Centre National Antiacridien (CNA). 2015. Rainfall database for southern Madagascar. CNA, Tuléar, Madagascar.

Challenge Program on Water and Food (CPWF). 2014. Breaking the trap. CPWF by the Consultative Group on International Agricultural Research (CGIAR). Montpellier, France. [online] URL: http://wle.cgiar.org/blogs/2014/05/05/breaking-trap/

Cinner, J. E. 2011. Social-ecological traps in reef fisheries. Global Environmental Change 21(3):835-839. http://dx.doi.org/10.1016/ j.gloenvcha.2011.04.012

Coral, C. 2014. Integration of smallholder farmers into agribusiness value chains under restrictive markets: the case of the LittoralMahafaly plateau transect in south-western Madagascar. Thesis. Humboldt University of Berlin, Germany. [online] URL: $\underline{\text { http:// }}$ repositorio.educacionsuperior.gob.ec/bitstream/28000/1488/1/TSENESCYT-00621.pdf

Dasgupta, P. 2007. Nature and the economy. Journal of Applied Ecology 44(3):475-487. http://dx.doi.org/10.1111/j.1365-2664.2007.01316. $\underline{\mathrm{X}}$

de Haut de Sigy, G. 1965. Etude agronomique de la cuvette d'Ankazomanga. Institut de recherches agronomiques à Madagascar, Antananarivo, Madagascar.

Dirac, C., L. Andriambelo, and J.-P. Sorg. 2006. Scientific bases for a participatory forest landscape management. Madagascar Conservation \& Development 1(1):31-33. http://dx.doi.org/10.4314/ mcd.v1i1.44041

Eakin, H. 2000. Smallholder maize production and climatic risk: a case study from Mexico. Climatic Change 45(1):19-36. http:// dx.doi.org/10.1023/A:1005628631627

Enfors, E. 2013. Social-ecological traps and transformations in dryland agro-ecosystems: using water system innovations to change the trajectory of development. Global Environmental Change 23(1):51-60. http://dx.doi.org/10.1016/j.gloenvcha.2012.10.007

Fauroux, E. 1989. Bœufs et pouvoirs. Pages 63-73 in A. Bourgeot and G. Henri, editors. Etats et sociétiés nomades. Politique Africaine, Paris, France.

Feldt, T. 2015. Interrelatedness of grazing livestock with vegetation parameters and farmers' livelihoods in the Mahafaly region, southwestern Madagascar. Dissertation. University of Kassel, Witzenhausen, Germany. [online] URL: https://kobra.bibliothek. uni-kassel.de/bitstream/urn:nbn:de:hebis:34-2015102749227/3/ DissertationTobiasFeldt.pdf

Fenn, M. D. 2003.The spiny forest ecoregion. Pages 1525-1530 in S. M. Goodman and J. P. Benstead, editors. The natural history of Madagascar. University of Chicago Press, Chicago, Illinois, USA.

Ferraro, P. J. 2002. The local costs of establishing protected areas in low-income nations: Ranomafana National Park, Madagascar. Ecological Economics 43(2-3):261-275. http://dx.doi.org/10.1016/ $\underline{\mathrm{S} 0921-8009(02) 00219-7}$ 
Folke, C., S. R. Carpenter, B. Walker, M. Scheffer, T. Chapin, and J. Rockström. 2010. Resilience thinking: integrating resilience, adaptability and transformability. Ecology and Society 15(4):20. http://dx.doi.org/10.5751/es-03610-150420

Food and Agriculture Organization of the United Nations (FAO). 2004. Minimum dietary energy requirement by country. FAO, Rome, Italy. [online] URL: http://www.fao.org/fileadmin/ templates/ess/documents/food security statistics/

MinimumDietaryEnergyRequirement en.xls

Food and Agriculture Organization of the United Nations (FAO). 2008. FAO methodology for the measurement of food deprivation. FAO, Rome, Italy. [online] URL: http://www.fao.org/fileadmin/ templates/ess/documents/food_security statistics/metadata/ undernourishment methodology.pdf

Food and Agriculture Organization of the United Nations (FAO). 2013. Response to the locust plague: three-year programme 2013-2016. FAO, Rome, Italy. [online] URL: http://www.fao.org/ fileadmin/user_upload/emergencies/docs/Locust-crisis-madagascarFAO en.pdf

Food and Agriculture Organization and World Food Program (FAO and WFP). 2014. FAO/WFP crop and food security assessment mission to Madagascar, 23 October. FAO, Rome, Italy. [online] URL: http://www.fao.org/3/a-I4111E.pdf

Ganzhorn, J. U., P. P. Lowry II, G. E. Schatz, and S. Sommer. 2001. The biodiversity of Madagascar: one of the world's hottest hotspots on its way out. Oryx 35(4):346-348. http://dx.doi. org/10.1046/j.1365-3008.2001.00201.X

Ghimire, K. B. 1994. Parks and people: livelihood issues in national parks management in Thailand and Madagascar. Development and Change 25(1):195-229. http://dx.doi.org/10.1111/ j.1467-7660.1994.tb00514.x

Götter, J. 2016. The cattle raiders leave us no choice: new transhumance in the Mahafaly Plateau region in Madagascar. Madagascar Conservation \& Development 11(1):12-22. http://dx. doi.org/10.4314/mcd.v11i1.3

Götter, J., O. Antsonantenainarivony, H. Rabemirindra, E. Schlecht, and F. Wätzold. 2015. Degradation of the important fodder tree Euphorbia stenoclada in southwest Madagascar and approaches for improved management. Page 3046 in Tropentag 2015. Management of land use systems for enhanced food security: conflicts, controversies and resolutions. September 16-18, Berlin, Germany. [online] URL: http://www.tropentag.de/2015/abstracts/ links/Goetter KoAhR9bd.pdf

Götter, J., and R. Neudert. 2015. From open access to a regime of mixed common- and private property: indigenous appropriation and regulation of the fodder tree Euphorbia stenoclada in southwest Madagascar. In Commons Amidst Complexity and Change, The Fifteenth Biennial Conference of the International Association for the Study of the Commons. September 25-29, Edmonton, Alberta, Canada. [online] URL: http://hdl.handle.net/10535/9833

Guyot, L. 2002. Reconnaissance hydrogéologique pour l'alimentation en eau d'une plaine littorale en milieu semi-aride. Dissertation. University of Nantes, France.
Hanisch, S. 2015. Improving cropping systems of semi-arid southwestern Madagascar under multiple ecological and socio-economic constraints. Dissertation. University of Kassel, Witzenhausen, Germany. [online] URL: https://kobra.bibliothek.uni-kassel.de/ bitstream/urn:nbn:de:hebis:34-2015070148664/9/

DissertationSusanHanisch.pdf

Hanisch, S., H. Hänke, A. Buerkert, and J. Barkmann. 2013. Agricultural innovations in cropping systems of semi-arid southwestern Madagascar under multiple ecological and socioeconomic constraints. In Tropentag 2013, Agricultural development within the rural-urban continuum. September 17-19, Stuttgart-Hohenheim, Germany. [online] URL: http://www. tropentag.de/2013/abstracts/links/Barkmann 94QJ2FC6.php

Hanjra, M. A., T. Ferede, and D. G. Gutta. 2009. Pathways to breaking the poverty trap in Ethiopia: investments in agricultural water, education, and markets. Agricultural Water Management 96(11):1596-1604. http://dx.doi.org/10.1016/j.agwat.2009.06.008

Hänke, H. 2016. Livelihoods on the edge: farming household income, food security and resilience in southwestern Madagascar. Dissertation, University of Göttingen, Göttingen, Germany. [online] URL: http://hdl.handle.net/11858/00-1735-0000-0028-8774$\underline{E}$

Hänke, H., and J. Barkmann. 2017. The insurance function of livestock: farmers' coping capacity with crop failure in southwestern Madagascar. World Development, in press.

Hänke, H., J. Barkmann, and J. Henitsoa. 2014. Rapport final de prestation sur: elaboration de la mise en oeuvre des activités génératrices de revenue ( $A G R s$ ) pour les paysans bénéficiaires de la GIZ 2014-2015. Mandated by Gesellschaft für internationale Zusammenarbeit (GIZ), Tuléar, Madagascar.

Hoerner, J. M. 1982. Les vols de boeufs dans le sud malgache. Madagascar:revue de géographie 41(1):85-105.

International Monetary Fund (IMF). 2015. IMF Country Report No. 15/25. Republic of Madagascar. IMF, Washington, D.C., USA. [online] URL: https://www.imf.org/external/pubs/ft/ scr/2015/cr1525.pdf

International Union for Conservation of Nature (IUCN). 2015. Global red list of endangered species. IUCN, Gland, Switzerland. [online] URL: http://www.iucnredlist.org/

Jasper, L., and C. Gardner. 2015. Life amongst the thorns: biodiversity \& conservation of Madagascar's Spiny Forest. John Beaufoy, Oxford, UK.

Johansson, S. 2010. Children in southern Madagascar still threatened by severe acute malnutrition. UNICEF, New York, New York, USA. [online] URL: http://www.unicef.org/childsurvival/ madagascar 54426.html

Kaufmann, J. C. 2004. Prickly pear cactus and pastoralism in southwest Madagascar. Ethnology 43(4):345-361. http://dx.doi. org/10.2307/3774032

Kaufmann, J. C., editor. 2008. Greening the Great Red Island: Madagascar in nature and culture. Africa Institute of South Africa, Pretoria, South Africa. 
Kiefer, I. 2011. Anpassung des Naturschutzes an Klimawandel und Landnutzungsänderungen zum Erhalt der einzigartigen biologischen Vielfalt des Dornenwaldes in Südwest-Madagaskar. Pages 105-110 in U. Feit and H. Korn, editors. Treffpunkt Biologische Vielfalt. Interdisziplinärer Forschungsaustausch im Rahmen des Übereinkommens über die biologischeVielfalt. Bundesamt für Naturschutz, Berlin, Germany. [online] URL: https://www.bfn.de/fileadmin/MDB/documents/service/skript289. pdf

Klein, J., B. Réau, and M. Edwards. 2008. Zebu landscapes: conservation and cattle in Madagascar. Pages 157-178 in J. C. Kaufmann, editor. Greening the Great Red Island: Madagascar in nature and culture. Africa Institute of South Africa, Pretoria, South Africa.

Kull, C. A. 2000. Deforestation, erosion, and fire: degradation myths in the environmental history of Madagascar. Environment and History 6(4):423-450. http://dx.doi.org/10.3197/096734000129342361

Kull, C. A. 2004. Isle of fire. The political ecology of landscape burning in Madagascar. University of Chicago Press, Chicago, Illinois, USA.

Kull, C. A. 2014. The roots, persistence, and character of Madagascar's conservation boom. Pages 146-171 in I. R. Scales, editor. Conservation and environmental management in Madagascar. Routledge, London, UK.

L'Institut National de la Statistique (INSTAT). 2011. Enquête periodique auprès des ménages 2010. Ministère de l'économie et de l'industrie. Antananarivo, Madagascar.

Making Markets Work for the Poor (M4P). 2006. Making value chains work better for the poor (M4P): a toolbook for practitioners of value chain analysis. Making Markets Work for the Poor (M4P) project. UK Department for International Development. Agricultural Development International, Phom Penh. Cambodia. [online] URL: http://aciar.gov.au/files/node/14580/

making value chains work better for the poor a to 14413.pdf

Manon, L. 2014. Cassava stock management by smallholder farming households in south-western Madagascar. Thesis. University of Lyon, Lyon, France.

Maru, Y. T., C. S. Fletcher, and V. H. Chewings. 2012. A Synthesis of current approaches to traps is useful but needs rethinking for indigenous disadvantage and poverty research. Ecology and Society 17(2):7. http://dx.doi.org/10.5751/ES-04793-170207

Mikulcak, F., J. L. Haider, D. J. Abson, J. Newig, and J. Fischer. 2015. Applying a capitals approach to understand rural development traps: a case study from post-socialist Romania. Land Use Policy 43:248-258. http://dx.doi.org/10.1016/j. landusepol.2014.10.024

Milleville, P., and C. Blanc-Pamard. 2001. La culture pionnière du mais sur abattis brûlis (hatsaky) dans le Sud-Ouest de Madagascar. 1. Conduite des systèmes de culture. Pages 243-254 in C. Razanaka, S. Grouzis, M. Milleville, P. Moizo, and B. Aubry, editors. Sociétés paysannes, transitions agraires et dynamiques écologiques dans le sud-ouest de Madagascar. Actes de l'atelier CNRE-IRD. CNRE-IRD, Antananarivo, Madagascar. [online] URL: http://www.documentation.ird.fr/hor/fdi:010046409
Milleville, P., M. Grouzis, S. Razanaka, and M. Bertrand. 2001. La culture pionnière du maïs sur abattis-brûlis (Hatsaky) dans le sud-ouest de Madagascar. 2. Evolution et variabilité des rendements. Pages 255-268 in C. Razanaka, S. Grouzis, M. Milleville, P. Moizo, and B. Aubry, editors. Sociétés paysannes, transitions agraires et dynamiques écologiques dans le sud-ouest de Madagascar. Actes de l'atelier CNRE-IRD.CNRE-IRD, Antananarivo, Madagascar. [online] URL: http://horizon. documentation.ird.fr/exl-doc/pleins textes/divers10-01/010046400. pdf

Minten, B., P. Méral, L. Randrianarison, and J. Swinnen. 2010. Trade liberalization, rural poverty and the environment: two studies of agricultural exports in Madagascar. Pages 78-97 in J. A. Cook, O. Cylke, D. F. Larson, J. D. Nash, and P. StedmanEdwards, editors. Vulnerable places, vulnerable people. Edward Elgar, Cheltenham, UK. http://dx.doi.org/10.4337/9781849805193.00013

Mitchell, J., and C. Coles, editors. 2011. Markets and rural poverty: upgrading in value chains. International Development Research Centre, Earthscan, London, UK.

Moreau, S. 2008. Environmental misunderstandings. Pages 49-68 in J. C. Kaufmann, editor. Greening the Great Red Island: Madagascar in nature and culture. Africa Institute of South Africa, Pretoria, South Africa.

Myers, N., R. A. Mittermeier, C. G. Mittermeier, G. A. B. da Fonseca, and J. Kent. 2000. Biodiversity hotspots for conservation priorities. Nature 403(6772):853-858. http://dx.doi.org/10.1038/35002501

Neudert, R., J. F. Goetter, J. N. Andriamparany, and M. Rakotoarisoa. 2015. Income diversification, wealth, education and well-being in rural south-western Madagascar: results from the Mahafaly region. Development Southern Africa 32(6):758-784. http://dx.doi.org/10.1080/0376835X.2015.1063982

Ploch, L., and N. Cook. 2012. Madagascar's political crisis. U.S. Congressional Research Service, Washington, D.C., USA. [online] URL: http://www.fas.org/sgp/crs/row/R40448.pdf

Ranaivoson, T., K. Brinkmannm, B. Rakouth, and A. Buerkert. 2015. Distribution, biomass and local importance of tamarind trees in south-western Madagascar. Global Ecology and Conservation 4(1):14-25. http://dx.doi.org/10.1016/j.gecco.2015.05.004

Ratovonamana, R. Y., C. Rajeriarison, E. Roger, I. Kiefer, and J. U. Ganzhorn. 2013. Impact of livestock grazing on forest structure, plant species composition and biomass in southwestern Madagascar. Scripta Botanica Belgica 50:82-92.

Réau, B. 2002. Burning for zebu: the complexity of deforestation issues in western Madagascar. Norsk Geografisk Tidsskrift 56:219-229. http://dx.doi.org/10.1080/00291950260293048

Scales, I. R. 2014. The future of conservation and development in Madagascar: time for a new paradigm? Madagascar Conservation and Development 9(1):5-12. http://dx.doi.org/10.4314/ mcd.v9i1.2

Sendzimir, J., C. P. Reij, and P. Magnuszewski. 2011. Rebuilding resilience in the Sahel: regreening in the Maradi and Zinder Regions of Niger. Ecology and Society 16(3):1. http://dx.doi. org/10.5751/ES-04198-160301 
Steneck, R. S., T. P. Hughes, J. E. Cinner, W. N. Adger, S. N. Arnold, F. Berkes, S. A. Boudreau, K. Brown, C. Folke, L. Gunderson, P. Olsson, M. Scheffer, E. Stephenson, B. Walker, J. Wilson, and B. Worm. 2011. Creation of a gilded trap by the high economic value of the Maine lobster fishery. Conservation Biology 25(5):904-912. http://dx.doi.org/10.1111/j.1523-1739.2011.01717. $\underline{\mathrm{X}}$

Sterman, J. D. 2000. Business dynamics: systems thinking and modeling for a complex world. Irwin/McGraw-Hill, Boston, Massachusetts, USA.

SuLaMa Marp. 2011. Diagnostic participatif de la gestion des resources naturelles sur le plateau Mahafaly. Sulama, Tuléar, Madagascar. [online] URL: http://www.sulama.de/files/ rapport marp 2011 mid.pdf

Tadross, M., L. Randriamarolaza, Z. Rabefitia, and K. Y. Zheng. 2008. Climate change in Madagascar: recent past and future. World Bank, Washington, D.C., USA. [online] URL: http://www.csag. uct.ac.za/ mtadross/Madagascar $\% 20$ Climate $\% 20$ Report.pdf

UNICEF. 2011. Le sud, cimétiere de projets?. UNICEF, New York, New York, USA. [online] URL: https://de.scribd.com/ document/70092972/Analyse-de-la-pauvrete-des-enfants-a-MadagascarUNICEF-2011

UNICEF. 2013. UNICEF Annual Report 2013 - Madagascar. UNICEF, New York, New York, USA. [online] URL: http://www. unicef.org/about/annualreport/files/Madagascar_COAR_2013.pdf

U.S. Department of Agricultural Research Service (USDA ARS). 2015. National nutrient database for standard reference release 28. USDA ARS, Washington D.C., USA. [online] URL: https://ndb. nal.usda.gov/ndb/search/list?qlookup $=\& q \mathrm{t}=\& \mathrm{manu}=$ \&SYNCHRONIZER URI $=\% 2$ Fndb $\% 2$ Fsearch $\%$

2Flist\&SYNCHRONIZER_TOKEN=67a4c44d-58f6-4e6e-9dc$\underline{\mathrm{f}-9 \mathrm{bcea} 589 \mathrm{~b} 18 \mathrm{f} \& \mathrm{ds}=\text { Standard }+ \text { Reference }}$

Usman, M. T., and C. J. C. Reason. 2004. Dry spell frequencies and their variability over southern Africa. Climate Research 26 (3):199-211. http://dx.doi.org/10.3354/cr026199

Virah-Sawmy, M. 2009. Ecosystem management in Madagascar during global change. Conservation Letters 2(4):163-170. http:// dx.doi.org/10.1111/j.1755-263X.2009.00066.X

Waeber, P. O., L. Wilmé, B. Ramamonjisoa, C. Garcia, D. Rakotomalala, Z. H. Rabemananjara, C. A. Kull, J. U. Ganzhorn, and J.-P. Sorg. 2015. Dry forests in Madagascar: neglected and under pressure. International Forestry Review 17(2):127-148. http://dx.doi.org/10.1505/146554815815834822

Wiseman, V., L. Conteh, and F. Matovu. 2005. Using diaries to collect data in resource-poor settings: questions on design and implementation. Health Policy and Planning 20(6):394-404. doi:10.1093/heapol/czi042 http://dx.doi.org/10.1093/heapol/czi042

World Bank. 2013. Madagascar: measuring the impact of the political crisis. World Bank, Washington, D.C., USA. [online] URL: http://www.worldbank.org/en/news/feature/2013/06/05/madagascarmeasuring-the-impact-of-the-political-crisis $\underline{\mathrm{http}: / / \mathrm{dx} \text {.doi. }}$ org/10.1596/0-8213-4551-6

World Bank. 2015a. Madagascar: poverty assessment. World Bank, Washington, D.C., USA. [online] URL: http://web.
worldbank.org/WBSITE/EXTERNAL/TOPICS/EXTPOVERTY/ EXTPA/0,,contentMDK:20204495 menuPK:443279 pagePK:148956 piPK:216618 theSitePK:430367,00.html

World Bank. 2015b. Madagascar population statistics database. World Bank, Washington, D.C., USA. [online] URL: http://data. worldbank.org/indicator/SP.POP.GROW?locations $=\mathrm{MG}$

World Bank. 2015c. Madagascar: systematic country diagnostic. World Bank, Washington, D.C., USA. [online] URL: http://wwwwds.worldbank.org/external/default/WDSContentServer/WDSP/ IB/2015/08/28/090224b0830a1a4f/1 0/Rendered/PDF/

Madagascar000S0c0country0diagnostic.pdf

World Food Program (WFP). 2013. Global food security update: tracking food security trends in vulnerable countries. Issue 12. WFP, Washington, D.C., USA. [online] URL: http://documents.wfp. org/stellent/groups/public/documents/ena/wfp260325.pdf

World Food Program (WFP). 2015a. Southern Africa food \& nutrition security working group. WFP, Washington, D.C., USA. [online] URL: http://documents.wfp.org/stellent/groups/public/ documents/ena/wfp278172.pdf

World Food Program (WFP). 2015b. Government, UN food agencies warn of deteriorating food security in southern Madagascar. WFP, Washington, D.C., USA. [online] URL: https://www.wfp.org/news/news-release/government-un-food-agencieswarn-deteriorating-food-security-southern-madagascar

World Food Program (WFP) and UNICEF. 2011. Comprehensive food and nutrition security and vulnerability analysis (CFSVA+ $N)$ : Rural Madagascar. WFP, Washington, D.C., USA. [online] URL: http://www.wfp.org/sites/default/files/MAG\%202010\%20CFSVA+ N_Full\%20report_English.pdf

Wolgin, J. M. 1975. Resource allocation and risk: a case study of smallholder agriculture in Kenya. American Journal of Agricultural Economics 57(4):622-630. http://dx.doi.org/10.2307/1238880

Wüstefeld, M. 2004. Bedeutung der Rinder für die Ernährungssicherung im semiariden Süden Madagaskars. Margraf, Eschborn, Germany. 
Appendix 1: Rainfall in the study region, Source: CNA 2015

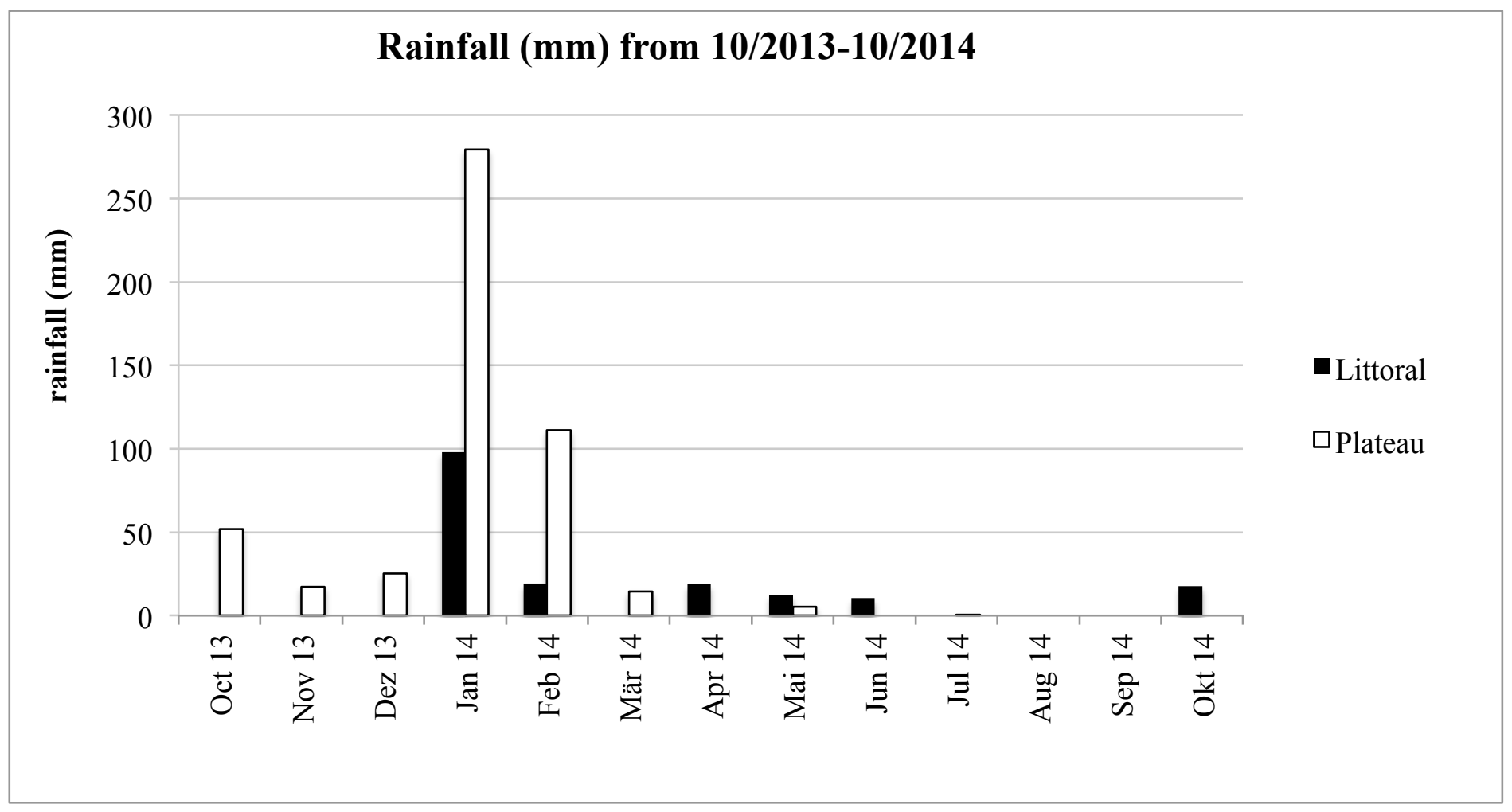


Appendix 2: Household cluster description, frequencies and sampling weights for regional extrapolation. Sampling weights of the cluster (strata) were calculated through: $\mathrm{Wi}=[(\mathrm{ni} / \mathrm{N}) /(\mathrm{si} / \mathrm{S})]$; where: $\mathrm{ni}=$ is the number of $\mathrm{HH}$ in strata $\mathrm{i}$ (absolute frequency in population), $\mathrm{N}=$ is the total number of $\mathrm{HH}$ in the sampling frame $(\mathrm{N}=507), \mathrm{si}=$ is the size of the sample having elements belonging to strata $\mathrm{i}$, (absolute frequency in stratified sample); $\mathrm{S}=$ is the size of the sample $(\mathrm{N}=140)$

\begin{tabular}{|c|c|c|c|c|c|c|}
\hline Cluster & Cluster description & $\begin{array}{l}\text { Absolute freq. } \\
\text { in population }\end{array}$ & $\begin{array}{c}\text { Relative } \\
\text { frequency in } \\
\text { population \% }\end{array}$ & $\begin{array}{c}\text { Absolute } \\
\text { frequency in } \\
\text { stratified sample }\end{array}$ & $\begin{array}{l}\text { Relative frequency in } \\
\text { stratified sample\% }\end{array}$ & $\begin{array}{l}\text { Sampling weight } \\
\text { for extrapolation }\end{array}$ \\
\hline 1 & Traders & 91 & 17.95 & 17 & 12.14 & 1.48 \\
\hline 2 & Livestock-rich & 31 & 6.11 & 15 & 10.71 & 0.57 \\
\hline 4 & Wage workers & 25 & 4.93 & 16 & 11.43 & 0.43 \\
\hline 5 & $\begin{array}{l}\text { Normal } \\
\text { agriculturalists }\end{array}$ & 131 & 25.84 & 18 & 12.86 & 2.01 \\
\hline 6 & $\begin{array}{l}\text { Forest-resource } \\
\text { dependent }\end{array}$ & 88 & 17.36 & 16 & 11.43 & 1.52 \\
\hline
\end{tabular}




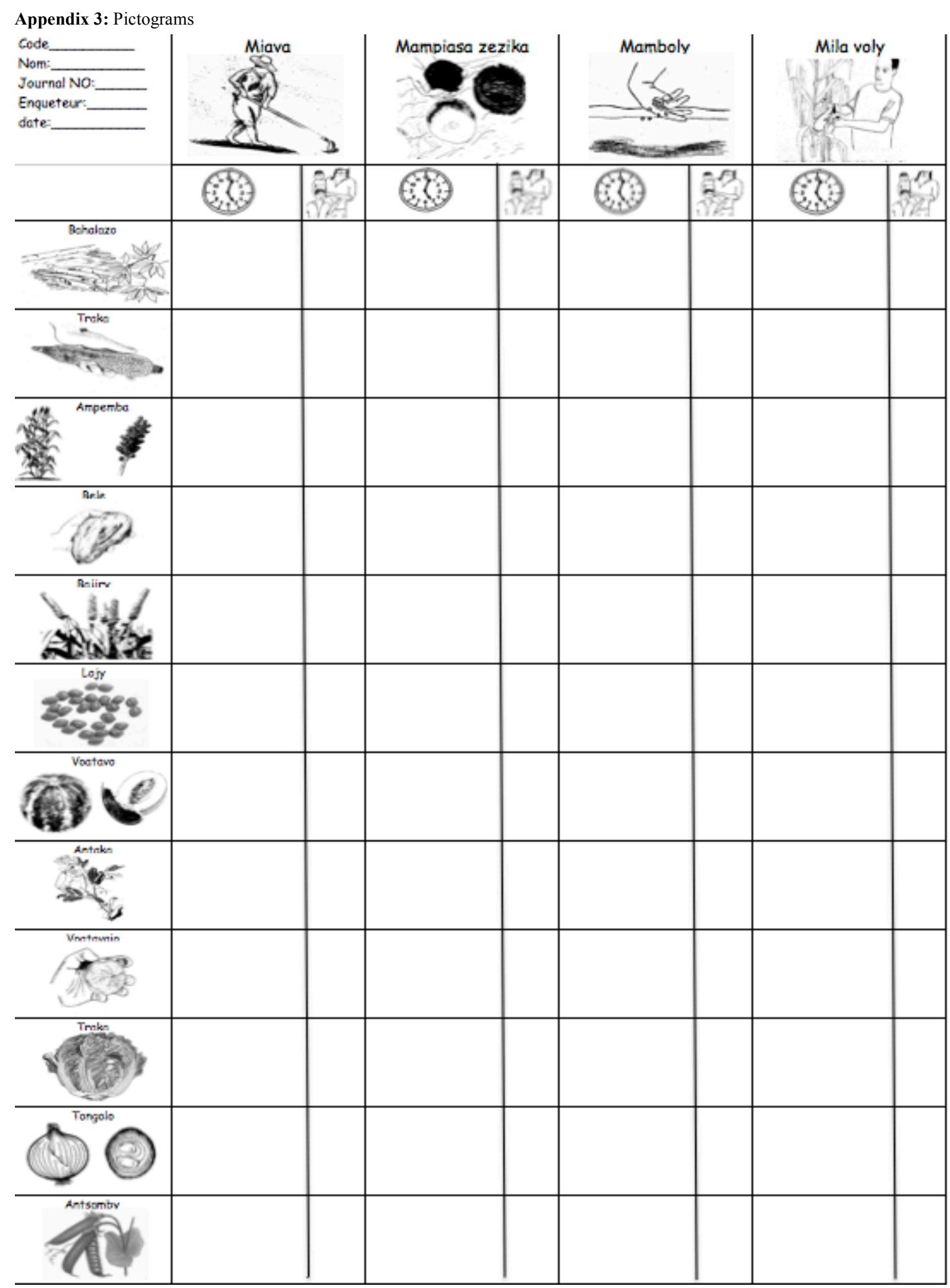




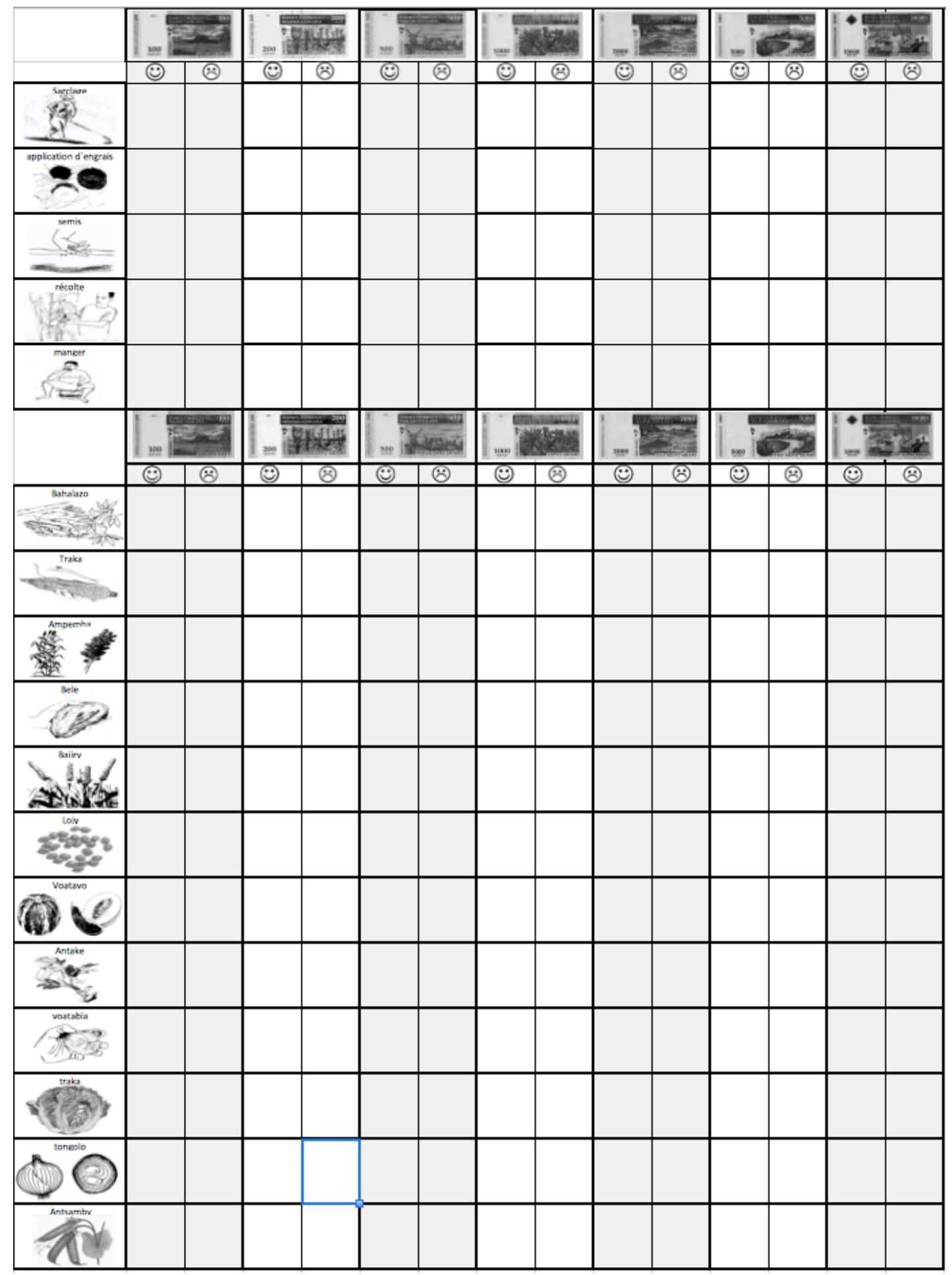




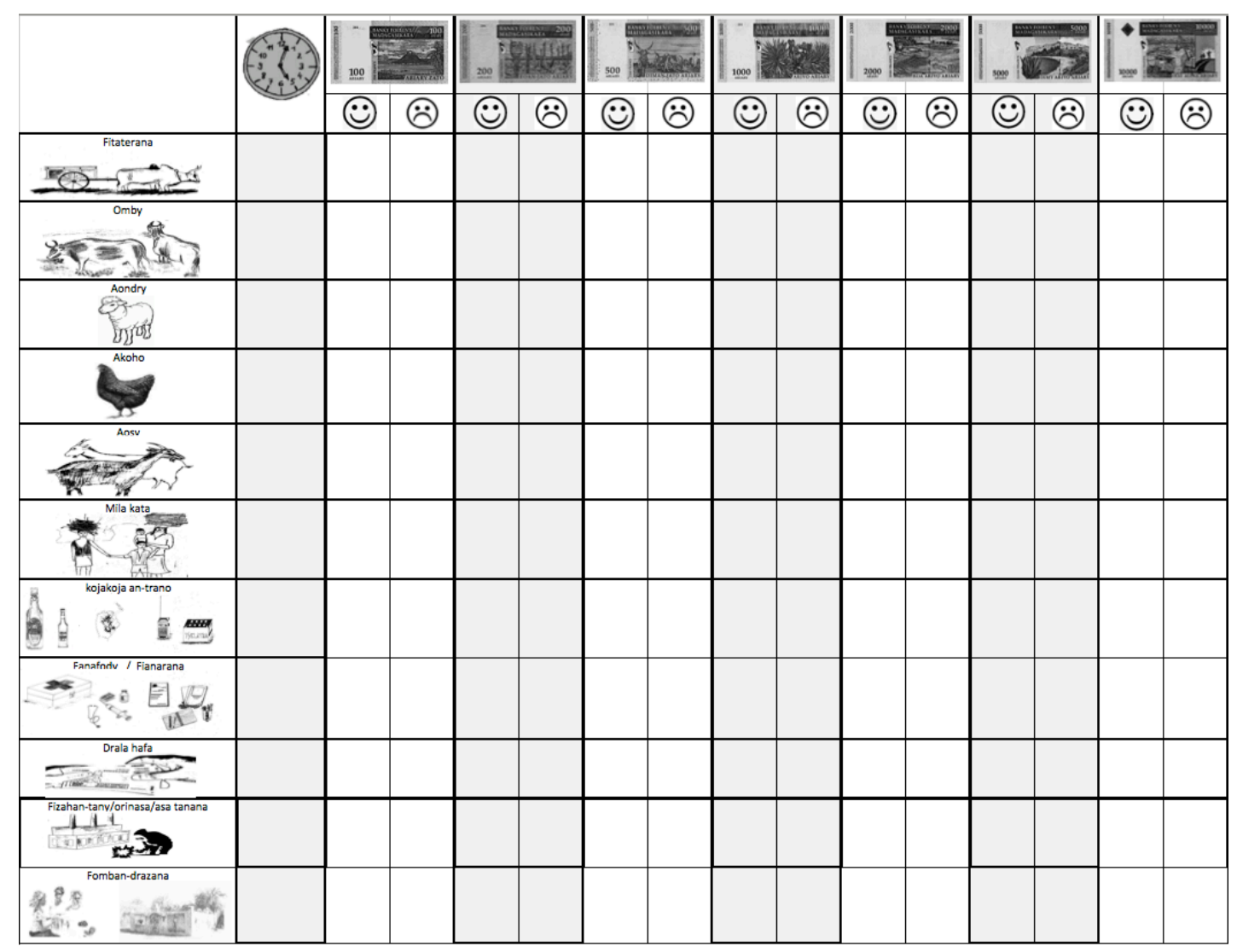


Appendix 4: Proportion of dry-wet and shell-seed proportions and local units for surveyed crops (Source: Proportion factors from Hanisch (2015), conversion factors to local units= own data)

\begin{tabular}{lccccccc}
\hline Crop & $\begin{array}{c}\text { Proportion } \\
\text { (pod/seeds) }\end{array}$ & $\begin{array}{c}\text { Proportion } \\
\text { (dry/wet) }\end{array}$ & $\begin{array}{c}\text { Pod sack } \\
(\mathbf{k g})\end{array}$ & $\begin{array}{c}\text { Seed sack } \\
(\mathbf{k g})\end{array}$ & $\begin{array}{c}\text { Oxcart } \\
(\mathbf{k g})\end{array}$ & $\begin{array}{c}\text { Basket } \\
(\mathbf{k g})\end{array}$ & $\begin{array}{c}\text { Kapok } \\
(\mathbf{k g})\end{array}$ \\
\hline Mais & 0.7 & 0.7 & 8.0 & 3.8 & 21.3 & 1.8 & 0.2 \\
Peanut & 0.6 & 0.8 & $*$ & 6.1 & 21.8 & 1.6 & 0.3 \\
Loyi & 0.7 & 1 & 4.5 & 3.7 & 47.9 & 0.7 & 0.3 \\
Millet & 0.7 & 1 & $*$ & 1.7 & 65.0 & & 0.3 \\
Antsamby & 0.6 & 1 & $*$ & 3.4 & 45.9 & 0.6 & 0.2 \\
Sorghum & 0.8 & 0.9 & $*$ & 2.2 & 32.9 & 1.7 & 0.2 \\
Antake & 0.7 & 1 & $*$ & 8.8 & 39.1 & 1.6 & 0 \\
Voanjabory & 0.8 & 0.9 & $*$ & 7.6 & $*$ & 1.3 & 0.2 \\
Cassava & $*$ & 0.4 & 4.7 & 1.2 & 143.2 & 1.7 & $*$ \\
\hline
\end{tabular}


Appendix 5: Regression analysis

\section{Regression analysis}

To illustrate the influence of rainfall on harvests, we regressed ${ }^{1}$ total harvest per household (kg, year 2014) on age and years of schooling of the household head, planted area (ha), rainfall (mm, year 2014) and the number of dry spells ( $>7$ days without rainfall in the rainy season January-May $2014^{2}$ (Hanisch 2015).

\section{Results}

The overall model was most highly significant $\left(\mathrm{P}_{\text {ANOVA }}<0.001\right)$ and explained $65.4 \%$ of the variance in harvest data. Toal planted area $(\mathrm{P}=<0.001)$, annual rainfall $(\mathrm{P}=0.005)$ and numbers of dry spells $(\mathrm{P}=0.002)$ were the only significant predictors of total harvest/yr/ha. Stepwise eliminating non-significant predictors yielded the same model. The standardised beta values of the coefficients confirmed that total planted area $(0.717)$ had the strongest influence on harvests, followed by total rainfall in 2014 (0.166). The occurrence of dry spells had a significant negative effect on harvests $(-0.155)$.

Model Summary

\begin{tabular}{|l|l|r|r|r|}
\hline Model & $\mathrm{R}$ & $\mathrm{R}$ Square & \multicolumn{1}{|c|}{ Adjusted R Square } & Std. Error of the Estimate \\
\hline 1 &, $808^{\mathrm{a}}$ &, 654 &, 641 & 811,896055900230700 \\
\hline
\end{tabular}

a. Predictors: (Constant), rainfall_mm, years of schooling, total planted area (ha), Age (HH head), dry

ANOVA $^{\mathrm{a}}$

\begin{tabular}{|ll|r|r|r|r|r|}
\hline Model & & Sum of Squares & df & Mean Square & \multicolumn{1}{|c|}{ F } & Sig. \\
\hline 1 & Regression & 172809918,809 & 5 & 34561983,762 & 52,432 &, $000^{\mathrm{b}}$ \\
& Residual & 91625353,577 & 139 & 659175,206 & & \\
& Total & 264435272,386 & 144 & & & \\
\hline
\end{tabular}

a. Dependent Variable: harvest $(\mathrm{kg})$

b. Predictors: (Constant), rainfall_mm, years of schooling, total planted area (ha), Age (HH head), dry spells (>7days)

\footnotetext{
${ }^{1}$ In multiple linear regression, the single predictors contribute in an additive fashion to predict the independent variable. Fundamental agricultural production theory (law of the minimum) requires a non-linear, mulitplicative model. In standard Cobb-Douglas production function analysis (Cobb and Douglas 1928), this is achieved by regressing the log of a harvest variable on the logs of socio-demographic, input and environmental variables. To illustrate the influence of rainfall on production in the most simple way, we opted for a simple regression analysis here following a reviewer comment.

${ }^{2}$ Concerning the 2013/2014 cropping season, the rainy season started in December 2013 (Hanisch 2015).

Unfortunately we don't have rainfall data for that month.
} 
Coefficients $^{\mathrm{a}}$

\begin{tabular}{|c|c|c|c|c|c|}
\hline \multirow[b]{2}{*}{ Model } & \multicolumn{2}{|c|}{ Unstandardized Coefficients } & \multirow{2}{*}{$\begin{array}{c}\text { Standardized Coefficients } \\
\text { Beta } \\
\end{array}$} & \multirow[b]{2}{*}{$\mathrm{t}$} & \multirow[b]{2}{*}{ Sig. } \\
\hline & $\mathrm{B}$ & Std. Error & & & \\
\hline 1 (Constant) & 309,694 & 449,922 & & ,688 & ,492 \\
\hline Age $(\mathrm{HH}$ head $)$ & $-3,125$ & 5,041 &,- 03 &,- 620 &, 536 \\
\hline Years of schooling & 32,061 & 22,435 & 07 & 1,429 &, 155 \\
\hline Total planted area (ha) & 357,132 & 26,511 &, 7 & 13,471 &, 000 \\
\hline Dry spells ( $>7$ days) & $-171,977$ & 60,208 &,- 15 & $-2,856$ &, 005 \\
\hline Rainfall (mm) & 1,107 & ,359 & 16 & 3,081 &, 002 \\
\hline
\end{tabular}

a. Dependent Variable: harvest $\mathrm{kg}$

\section{LITERATURE CITED}

Cobb, C. W., and P. H. Douglas. 1928. A Theory of Production. American Economic Review 18(1):139-165.

Hanisch, S. 2015. Improving cropping systems of semi-arid south-western Madagascar under multiple ecological and socio-economic constraints. Doctoral Dissertation. University of Witzenhausen. 
Appendix 6: Seasonality of food production, Source: market participation survey

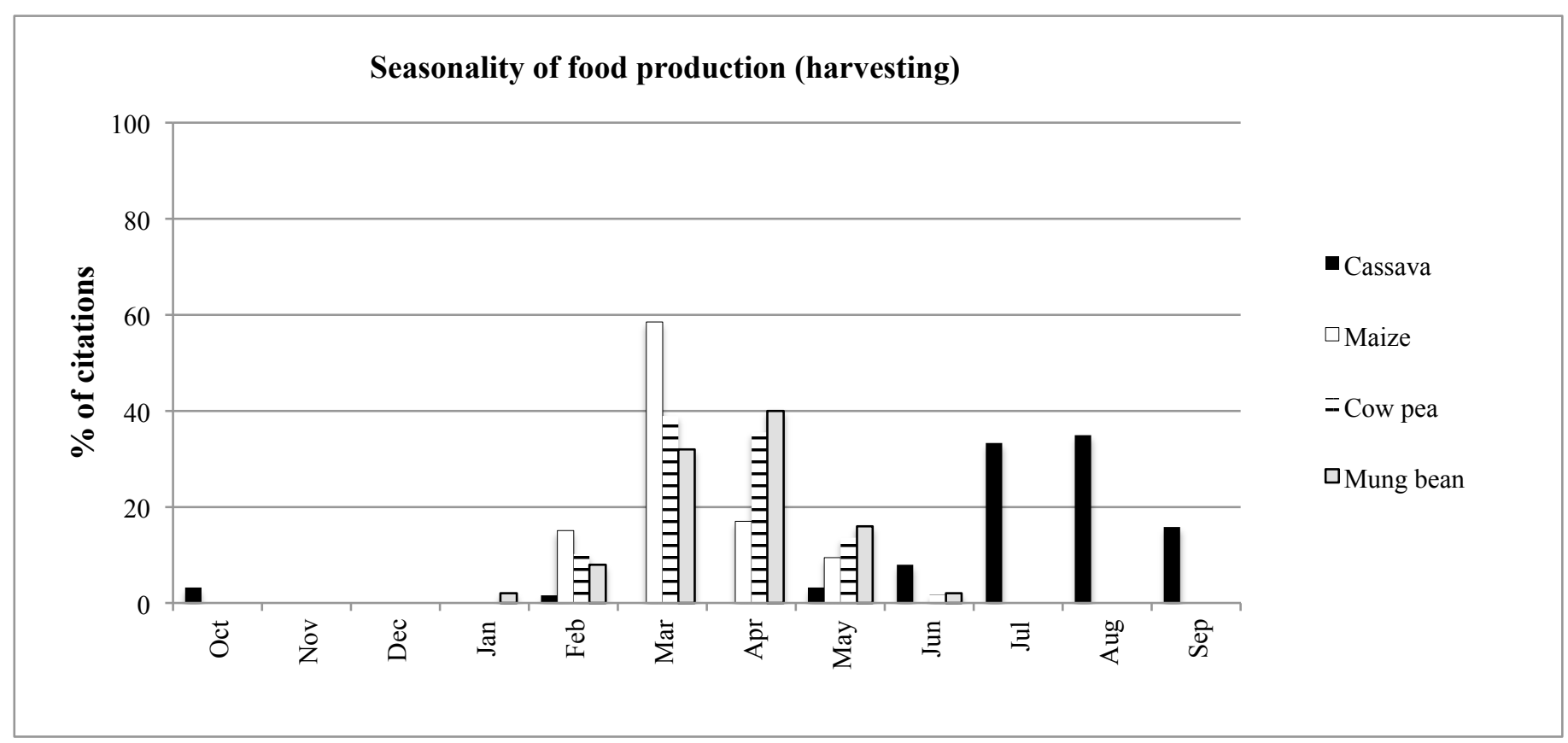

